IZA DP No. 9994

Is Partisan Alignment Electorally Rewarding?

Evidence from Village Council Elections in India

Subhasish Dey

Kunal Sen

June 2016 


\title{
Is Partisan Alignment Electorally Rewarding? Evidence from Village Council Elections in India
}

\author{
Subhasish Dey \\ University of Manchester
}

\author{
Kunal Sen \\ University of Manchester \\ and IZA
}

\author{
Discussion Paper No. 9994 \\ June 2016
}

IZA
P.O. Box 7240
53072 Bonn
Germany

Phone: +49-228-3894-0

Fax: +49-228-3894-180

E-mail: iza@iza.org

Any opinions expressed here are those of the author(s) and not those of IZA. Research published in this series may include views on policy, but the institute itself takes no institutional policy positions. The IZA research network is committed to the IZA Guiding Principles of Research Integrity.

The Institute for the Study of Labor (IZA) in Bonn is a local and virtual international research center and a place of communication between science, politics and business. IZA is an independent nonprofit organization supported by Deutsche Post Foundation. The center is associated with the University of Bonn and offers a stimulating research environment through its international network, workshops and conferences, data service, project support, research visits and doctoral program. IZA engages in (i) original and internationally competitive research in all fields of labor economics, (ii) development of policy concepts, and (iii) dissemination of research results and concepts to the interested public.

IZA Discussion Papers often represent preliminary work and are circulated to encourage discussion. Citation of such a paper should account for its provisional character. A revised version may be available directly from the author. 


\section{ABSTRACT}

\section{Is Partisan Alignment Electorally Rewarding? Evidence from Village Council Elections in India*}

Do ruling parties positively discriminate in favour of their own constituencies in allocating public resources? If they do, do they gain electorally in engaging in such a practice? This paper tests whether partisan alignment exists in the allocation of funds for India's largest social protection programme, the National Rural Employment Guarantee Scheme (NREGS) in the state of West Bengal in India, and whether incumbent local governments (village councils) gain electorally in the practice of partisan alignment. Using a quasi-experimental research design, we find that the village council level ruling-party spends significantly more in its own party constituencies as compared to opponent constituencies. We also find strong evidence of electoral rewards in the practice of partisan alignment. However, we find that the results differ between the two main ruling political parties at the village council level in the state.

JEL Classification: H53, I38

Keywords: National Rural Employment Guarantee Scheme, partisan alignment feedback effect, fuzzy regression discontinuity design

Corresponding author:

Subhasish Dey

School of Social Sciences

University of Manchester

Arthur Lewis Building

Manchester M13 9PL

USA

E-mail: subhasish.dey@manchester.ac.uk

\footnotetext{
* We acknowledge the comments and feedbacks from Katsushi Imai, Debjani Dasgupta, Mohammad Rahman, Nisith Prakash, Abhiroop Mukhopadhay, Sam Asher and conference and seminar participants at ISI, Kolkata, BASAS Conference, Brown Bag Seminar at Manchester, 3ie Delhi.
} 


\section{Introduction}

An influential literature has highlighted the role of political incentives in the allocation of public resources from upper tier to lower tier governments (Case 2001, Stromberg 2002, Johansson 2003, Dahlberg and Johansson 2002, Banful 2011a and 2011b). A common finding in this literature is the presence of partisan alignment - upper tier government allocate more funds to lower tier governments or to constituencies which they control (that is, which are aligned with the upper tier government) than to lower tier governments or to constituencies which are in the control of opposition parties (that is, which are unaligned with the upper tier government) in federal political systems (Dasgupta et al. 2004, Sole-Olle and Sorribas-Navarro 2008, Asher and Novosad 2015). The empirical evidence so far on the presence of partisan alignment has been mostly to do with intergovernmental transfers or grants, and there is limited evidence on whether partisan alignment is also evident for other public programmes where resources flow from upper tier to lower tier government or constituencies. ${ }^{1}$ It is also not clear whether partisan alignment is indeed electorally rewarding - can allocating upper tier governments expect stronger political support from the lower tier governments or constituencies that they are targeting? A final unresolved issue in the literature is whether political parties differ in their practice of partisan alignment, depending on their ideology or policy preferences.

This paper examines whether ruling parties in local governments in the state of West Bengal in India discriminate in favour of their own constituencies in allocating funds for a large national social protection programme called the National Rural Employment Guarantee Scheme (NREGS). It then analyses the effect of partisan alignment in NREGS fund allocation, where it exists, on the vote share of the ruling party and the probability of reelection in the next local government elections. Since different political parties with very different ideologies were in power at the local government level in different parts of the state, we are also able to test for heterogeneous policy preferences in the practice of partisan alignment by ruling political parties at the local government level in West Bengal.

\footnotetext{
${ }^{1}$ A related literature in the political economy of redistribution has examined the role of political patronage and clientelist politics in explaining the allocation of public funds or the implementation of government programmes (Bardhan and Mookherjee, 2006, 2012; Caselli and Michaels, 2009). This literature finds that the public spending is allocated to certain social groups in the electorate based on political patronage and not solely on efficiency or equity considerations (Bardhan and Mookherjee, 2012; Gervasoni, 2010; Goldberg, et al. 2008).
} 
Theoretically, it is ambiguous whether political parties will target constituencies where voters clearly attached to the incumbent party or constituencies which are held by the opposition party in an effort to wrest control of these constituencies from the opposition party. Electoral competition models suggest that governments should allocate more resources to unaligned constituencies (Lindbeck and Weibull 1987, Dixit and Londegran 1996). On the other hand, if politicians are risk averse or are motivated by clientelist concerns they will allocate more funds to their core constituencies (Cox and McCubbins 1986). Arulampalam et al. (2009) develop a model of redistributive politics where the upper tier government allocates more funds to lower tier governments that are both aligned and relatively more swing (that is, lower tier governments where the ruling party in the upper tier faces stronger political competition).

A similar ambiguity exists in the theoretical literature on whether the practice of partisan alignment will indeed be electorally rewarding for the incumbent political party. Since there is no formal way to contract for votes in an election with secret ballots, politicians and voters may be unable to credibly commit to an exchange where the politician offers additional public funds to voters in exchange for increased support at the ballot box (Robinson and Verdier 2003). Partisan alignment may be electorally rewarding if voters reciprocate because they experience pleasure in increasing the material payoffs of the politicians who helped them (Finan and Schechter 2012). On the other hand, particularistic redistribution policies may not necessarily lead to positive electoral rewards if citizens have social preferences for certain political parties or candidates, independent of whether the incumbent party or politician in power has helped them or not (Kartik and McAfee 2007). A large empirical literature that has examined whether targeted government programs increase pro-incumbent voting has found mixed evidence in support of positive electoral gains for incumbents when they engage in clientelistic exchanges with voters (Manacorda et al. 2011, Zucco 2011, De La O 2013, Labonne 2013).

An econometric challenge in identifying whether partisan alignment exists in the delivery of public programmes is that a positive association that may be observed between the allocation of public funds to a constituency and whether the constituency is under the control of the incumbent party could be due to certain characteristics of the politician (such as an innate preference to favour certain groups of voters) or the constituency (such as past support for the political party) that may lead the incumbent politician to allocate more resources to that 
constituency. To address this concern, we use a quasi-experimental design (Fuzzy Regression Discontinuity Design (FRDD)) as our principal estimation method to address whether partisan alignment occurs in NREGS implementation. A similar econometric challenge exists in identifying the effect of partisan alignment, wherever it occurs, as voters may prefer a particular party or candidate for reasons other than whether the NREGS was implemented well in the constituency or not. To identify the causal feedback effect of partisan alignment on vote share (or the likelihood of re-election) of the incumbent political party in the next election, we use an indirect least squares strategy where we use the NREGS outcome that can be causally related to partisan alignment (which we obtain from the FRDD method) as our main explanatory variable.

To test for the presence of partisan alignment and its electoral rewards, we use a rich primary data set from 569 villages (or village council wards) over 49 Village Councils or Gram Panchayats (GP) from 3 districts of West Bengal. This village level panel data has 3 waves (2010, 2011 and 2012) preceded and followed by one election year i.e. 2008 and 2013 respectively. During our study period (2008 to 2013), there were two principal contesting parties in West Bengal with dissimilar political ideologies: a coalition of Leftist parties - the Left Front (LF) -led by the Communist Party of India (Marxist) (CPIM) with an apparently stated commitment of democratic decentralisation and pro-worker policies (Bardhan and Mookherjee 2012) and a right-of-centre Trinamool Congress (TMC) with an apparently populist agenda of giving direct benefits to its supporters (Bhattacharya 2012, Mallik 2013). The fact that there were two political parties in different parts of the state running the village councils allows us to assess whether there was any heterogeneous policy preferences of these two parties in respect of delivering NREGS funds, and if there was such a heterogeneity, whether the electoral returns to the practice of partisan alignment differed across the two main political parties.

We find clear evidence of partisan alignment - after the 2008 Panchayat elections, the ruling party at the GP level significantly spent more NREGS funds in all the following years in their own party constituencies as compared to the constituencies of their opponents. However, we find that the practice of partisan alignment differed between the two main political parties while TMC run GPs practised partisan alignment, CPIM run GPs did not. We also find strong electoral returns to the practice of partisan alignment -GPs ruled by TMC after 2008 Panchayat Election managed to secure a higher percentage of vote as well as higher 
probability of re-election in their own constituencies in the following 2013 Panchayat election, while such an outcome was not observed for LF run GPs.

The remainder of this paper is organised as follows. Section 2 discusses the political context of the NREGS in West Bengal. Section 3 discusses the data and descriptive statistics. Section 4 describes the empirical strategy. Section 5 presents the results. Section 6 discusses the possible explanations of our results on the difference in the alignment behaviour of the TMC and LF. Section 7 presents the conclusions.

\section{Political Context of the NREGS in West Bengal}

In India's federal structure, significant political power is decentralised to Gram Panchayats, under a system of local government in rural India known as Panchayati Raj. While the idea of Panchayati Raj was embodied as an aspiration in the Indian constitution, implementation of the system of local government was devolved to Indian state governments (Crook and Sverrisson 2001). West Bengal passed its first Panchayat Act in 1973 and the $1^{\text {st }}$ Panchayat election was held in 1978, much ahead of any other state in India.

Local government in rural India has three tiers. The district level government is called the Zilla Parishad (ZP), the sub-district or block level government is called the Panchayat Samity (PS) and the lowest tier of government, which is the village council, is called the Gram Panchayat (GP). A GP has a number of villages or wards, called Gram Sansad (GS), typically around 10-15 GS in GP. Elections to GPs take place every five years and are held at the ward or GS level to choose a ward representative from each of the wards under the GP. There are 3357 GPs and $45552 \mathrm{GS} /$ wards in West Bengal.

In the West Bengal case, GP elections are a multi-party election (during 2008-2013, 7 political parties took part in the elections in our study area). However, the major contesting parties are mainly two in West Bengal - the Trinamul Congress (TMC) and the Left Front. Within a GP, a party which wins the majority of wards or GS forms the GP board and become the GP level ruling party and runs the GP for 5 years. Around 25 poverty alleviation and public works programmes are implemented by the GP. Among these programmes, the National Rural Employment Guarantee Scheme (NREGS) is the most important and endowed with the highest proportion of money. An average GP normally spends around 25 to 30 million INR (i.e. 250-300 thousand GBP) among which 85\% to $90 \%$ allocation comes for NREGS. 
The NREGS is India's main welfare programme for the rural poor and the largest workfare programme in the world, covering 11 per cent of the world's population (Muralidharan et al. 2015). The act associated with the NREGS makes it a statutory obligation for the government to provide minimum 100 days of employment on demand to each rural household in India. The programme came in operation in February 2006 in the most backward 200 districts of India including 10 districts from West Bengal. Subsequently, in the second phase of the programme, NREGS was scaled up to another 130 districts of India by 2007 including 7 districts from West Bengal. In its third and final phase, the remaining 285 districts of India were included (with 1 district from West Bengal).

Under the programme, there is no eligibility requirements as the manual nature of the work involved is expected to lead the poor into program participation (Besley and Coate 1992). Participating households obtain job cards, which are issued by the local GP. Once issued a job card, workers can apply at will to the local GP or block office. Officials are legally obligated to provide work on projects within 5 kilometres of the worker's home. The projects vary greatly, though road construction and irrigation earthworks predominate (Niehaus and Sukhtankar 2013). The administration of the projects is the responsibility of the GP.

\section{Evolution of Political Institutions}

From 1977 to 2011, a Left political coalition (the LF) led by the Communist Party of India (Marxist) (CPIM) was uninterruptedly in power both at the state and the local levels of government, with clear majorities in the number of seats in the State Assembly (Table 1).

Table 1: Year wise Left front seat share in State Assembly Elections, 1977 to 2016

\begin{tabular}{cc}
\hline Year of Assembly Election & Percentage of seat won by Left front \\
\hline 1977 & 60.20 \\
1982 & 77.55 \\
1987 & 82.31 \\
1991 & 81.97 \\
1996 & 69.05 \\
2001 & 66.05 \\
2006 & 79.93 \\
2011 & 21.09 \\
\hline 2016 & 10.88 \\
\hline
\end{tabular}

Source: Official website of West Bengal State Assembly: http://wbassebmly.gov.in and official website of Election Commission of India: http://eci.nic.in/eci/eci.html 
Till 1997, the Indian National Congress (Congress) was the major opponent political party in West Bengal but from $1^{\text {st }}$ January 1998 a fraction of the Congress party broke away and formed a new political party-the All India Trinamool Congress (TMC) led by Mamata Banerjee. Soon after its inception TMC had been able to establish itself as the main opponent of the LF in the state. The ideology of the TMC could be broadly classified as Right Populist (Mallik, 2013; Bhattacharya, 2012; Rana 2013).

At the local government level, there has been gradual erosion of support for the LF from the 1980s onwards, along with a sharp increase in the electoral success of the TMC in local government elections. Table 2 shows that the vote share of Left Front fell sharply in GP elections from 1978 to 2013.

Table 2: GP level Vote share of Left Front in Panchayat Elections, 1978-2013

\begin{tabular}{cc}
\hline Year & GP level Vote Share of the Left Front \\
\hline 1978 & 70.28 \\
2003 & 65.75 \\
2008 & 52.98 \\
2013 & 32.01 \\
\hline
\end{tabular}

Source: Author's calculation from CPIM party documents and West Bengal State Election Commission Website.

Figure 1 shows seat share of major political parties (or party coalition) in Zilla Parishad elections over the years in West Bengal. It clearly shows that from 2003 onwards, the TMC started gaining in electoral success and by 2013 it became the ruling party in the district level local governments as well. Figure 2 shows the winning party in each district in Zilla Parishad elections in 2003, 2008 and 2013. In 2003, most Zilla Parishads were ruled by the LF; however, by 2013, the LF had lost control of most of these district level local governments to the TMC. 
Figure 1: Seat share of Major Political Parties in Zilla Parishad Elections, 1978-2013

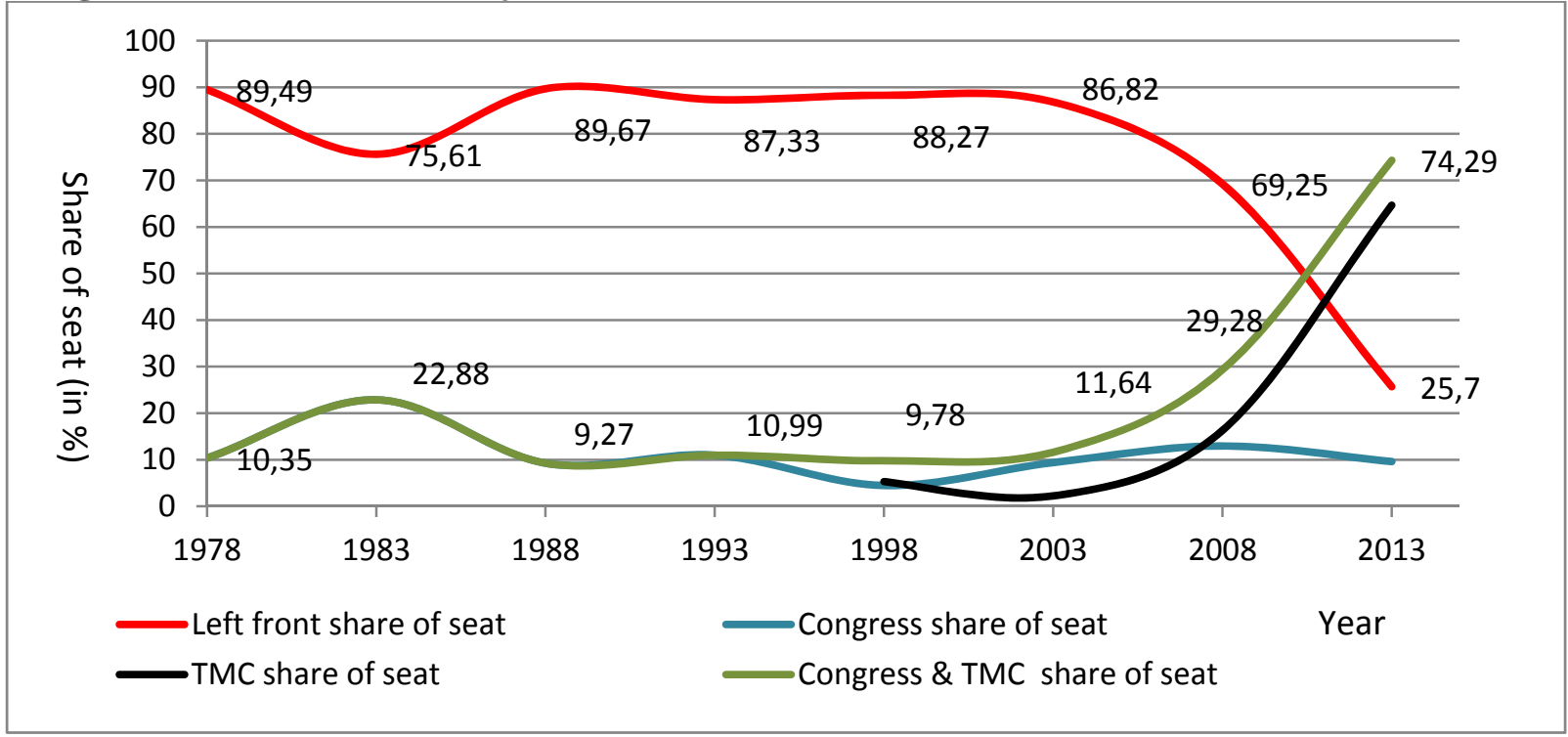

Source: Author's calculation from a) West Bengal State Election commission website

b) Panchim Banga Saptam Panchayat Nirbachan-2008: c) Porisankhan-o-Parjalochana, from Communist Party of India (Marxist), West Bengal State Committee, 2013.

Figure 2: District wise Ruling Party Position after Local Government Elections in 2003, 2008 and 2013

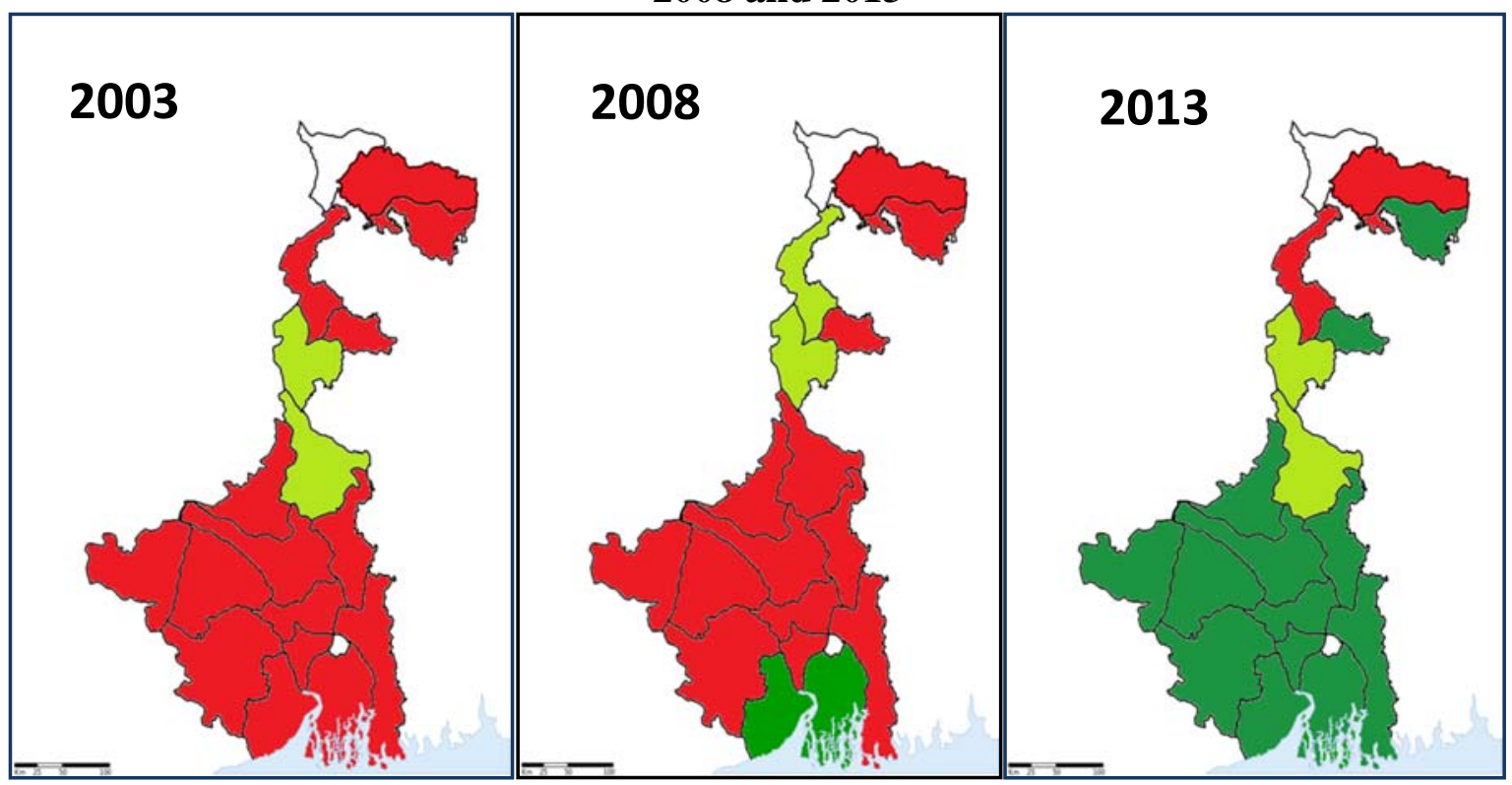

CPIM: Congress: TMC:

Note: White sections in the maps above show the area where there was no District Panchayat Source: Author's calculation from West Bengal State Election commission website 


\section{Data and Summary Statistics}

\section{Data}

The unit of our study is village (or GS i.e. ward of the village council). Our sample consists of a three wave $(2010,2011,2012)$ panel of 569 villages from 49 different Gram Panchayats (i.e. the Village Councils) over 3 districts of West Bengal, namely South-24 Parganas (S24Pgs), Purulia and Jalpaiguri. This panel data set contains village wise yearly information on NREGS implementation during 2010-2012, GP election outcomes for the 2008 and 2013 elections for each village, socio-economic-demographic information for each village, monthly and annual average rain fall for each village. From our primary survey we collected information on village wise NREGS implementation and other public expenditure through GP at the village level. The two NREGS outcome variables we use in our empirical analysis are village wise NREGS expenditures and average NREGS days worked per NREGS household in the village.

Election outcomes for the 2008 and 2013 village wise were collected from the official website of the West Bengal State Election Commission. Village wise socio-economic information was collected from the West Bengal Rural Household Survey-2011. Demographic information was collected from Census-2011, Government of India. Rainfall data (which we use as one of our controls) was collected from the precipitation data available from the Centre for Climate Research at the University of Delaware. The data include monthly precipitation values at 0.5 degree intervals in latitude and longitude. To match the data at the village/sansad level, nearest latitude-longitude to each village was taken.

Table 3 provides a party-wise allocation of winning seats at village level in respect of our sample of 569 villages in two successive Panchayat Elections 2008 and 2013. This clearly shows that even for our sample villages from 3 districts of West Bengal there is a clear picture of a shift in election outcomes in favour of TMC from 2008 to 2013 in line with state level trends. Table 4 shows the share of different parties in GP boards where they were ruling parties for the 2008 and 2013 elections. From this table, we can see that out of our sample of 49 Gram Panchayats, in 2008 there were overall 30.61\% of GPs where TMC was the ruling party and $57.1 \%$ GPs where Left Ally was the ruling party. In 2013, this changed dramatically, with the TMC appearing as the ruling party in $61.2 \%$ of GP boards, while only $24.5 \%$ of GP boards were ruled by the CPIM or an allied party of the Left Front. 
Table 3: Party wise village level election results by seats won

\begin{tabular}{ccc}
\hline Party & \% of seat won in 2008 & \% of seat won in 2013 \\
\hline TMC & 27.89 & 48.68 \\
CPIM & 48.51 & 29.88 \\
Left Ally & 7.62 & 4.92 \\
Congress & 11.42 & 6.50 \\
SUCI & 1.58 & 2.64 \\
Independent & 2.69 & 3.69 \\
Other (JMM, BJP, etc.) & 0.29 & 3.69 \\
\hline Total & 100 & 100
\end{tabular}

Source: From West Bengal State Election Commission website for 569 study Gram Sansads.

Table 4: GP Board allocation by Ruling Party

\begin{tabular}{llllll}
\hline Year & District & $\begin{array}{l}\text { \% GP board by } \\
\text { TMC }\end{array}$ & $\begin{array}{l}\text { \% GP board by } \\
\text { CPIM \& Left Ally }\end{array}$ & $\begin{array}{l}\text { \% GP board by } \\
\text { Congress }\end{array}$ & $\begin{array}{l}\text { \% GP board by } \\
\text { other }\end{array}$ \\
\hline \multirow{2}{2}{2008} & S-24pgs & 45.45 & 45.45 & 4.55 & 4.55 \\
& Purulia & 31.25 & 50 & 12 & 6.25 \\
& Jalpaiguri & 0 & 90.91 & 9.09 & 0 \\
\cline { 2 - 6 } 2013 & Overall & 30.61 & 57.14 & 8.16 & 4.08 \\
\cline { 2 - 6 } & S-24pgs & 59.09 & 36.36 & 0 & 4.55 \\
& Purulia & 93.75 & 6.25 & 0 & 0 \\
& Jalpaiguri & 18.18 & 27.27 & 27.27 & 27.27 \\
\cline { 2 - 6 } & Overall & 61.22 & 24.49 & 6.12 & 8.16 \\
\hline
\end{tabular}

Source: From West Bengal State Election Commission website for 49 GPs.

Tables 3 and 4 also show the representativeness of our sample with reference to the overall trend of the state. In Table 5 we observe a similar story not in terms of winning village level seats or ruling GPs rather in terms of actual vote share secured by different parties at village level between these two successive panchayat election years 2008 and 2013 in context of 569 GS.

Table 5: Village wise percentage of votes received by different parties

\begin{tabular}{ccccccccc}
\hline \multirow{2}{*}{ Year } & \multirow{2}{*}{ District } & $\begin{array}{c}\text { \% TMC } \\
\text { Vote }\end{array}$ & $\begin{array}{c}\text { \% CPIM } \\
\text { vote }\end{array}$ & $\begin{array}{c}\text { \% other } \\
\text { Left vote }\end{array}$ & $\begin{array}{c}\text { \% Congress } \\
\text { Vote }\end{array}$ & $\begin{array}{c}\text { \% SUCl } \\
\text { vote }\end{array}$ & $\begin{array}{c}\text { \% Indep. } \\
\text { Vote }\end{array}$ & $\begin{array}{c}\text { \% other } \\
\text { vote }\end{array}$ \\
\hline \multirow{4}{*}{2008} & S- 24pgs & 30.69 & 45.86 & 7.83 & 4.537 & 3.16 & 4.66 & 0.464 \\
& Purulia & 23.72 & 44.85 & 5.345 & 10.69 & 0 & 6.760 & 3.3744 \\
& Jalpaiguri & 4.47 & 46.93 & 15.935 & 24.21 & 0 & 3.3544 & 1.695 \\
\cline { 2 - 9 } 2013 & Overall & 22.79 & 45.82 & 8.94 & 10.73 & 1.55 & 4.97 & 1.57 \\
\cline { 2 - 9 } & S-24pgs & 44.37 & 34.19 & 5.96 & 1.50 & 5.817 & 2.14 & 1.063 \\
& Purulia & 44.63 & 29.84 & 3.9 & 9.47 & 0.525 & 4.44 & 0.7038 \\
& Jalpaiguri & 21.15 & 20.62 & 6.71 & 21.76 & 0 & 10.77 & 12.41 \\
\hline & Overall & 39.23 & 29.89 & 5.54 & 8.34 & 2.99 & 4.74 & 3.51 \\
\hline
\end{tabular}

Source: From West Bengal State Election Commission website for 569 study Gram Sansads 


\section{Summary Statistics}

In our study we used data from two consecutive Panchayat election years 2008 and 2013. To see whether there is any significant degree of divergence in terms of summary statistics of the variables related to election outcomes, we present in Table 6 the village level average values of the election related variables over the two elections years over our sample of 569 villages.

Table 6: Summary Statistics on Election Related Variables over 2008 and 2013 at village level

\begin{tabular}{|c|c|c|c|}
\hline Category & $\begin{array}{c}\text { Average value in } \\
2008\end{array}$ & $\begin{array}{l}\text { Average value } \\
\text { in } 2013\end{array}$ & $\begin{array}{l}\text { t-statistics on the } \\
\text { Mean Difference. }\end{array}$ \\
\hline Total voters in a village & 1003.243 & 925.66 & $8.83 * * *$ \\
\hline Percentage of voters casted vote & 85.8589 & 85.76464 & 0.3418 \\
\hline $\begin{array}{l}\text { Percentage of vote received by the } \\
\text { winning candidate }\end{array}$ & 56.74265 & 51.0522 & $13.4066^{* * *}$ \\
\hline $\begin{array}{l}\text { Percentage of vote received by } \\
\text { nearest defeated candidate }\end{array}$ & 35.0773 & 35.52725 & -1.2415 \\
\hline Margin of Win & 189.5647 & 126.3175 & $8.7037 * * *$ \\
\hline $\begin{array}{l}\text { Winning margin as percentage of } \\
\text { total vote casted }\end{array}$ & 21.66535 & 15.5413 & $8.6436 * * *$ \\
\hline $\begin{array}{l}\text { Percentage of vote other defeated } \\
\text { candidates received altogether. }\end{array}$ & 8.172214 & 13.41469 & $-15.0694^{* * *}$ \\
\hline
\end{tabular}

Source: Authors calculation from Election outcome data on sample 569 village from West Bengal State Election Commission website: http://www.wbsec.gov.in

Table 6 shows that from 2008 to 2013, average number of voters in each village has decreased by around 78 but percentage of voters casted their vote remains almost same. We also note that the vote share received by the winning candidate fell by 5.7 percentage points from 2008 to 2013, while the margin of win as a percentage of total votes casted reduced by 6.1 percentage points in the same period. On the other hand, percentage of vote received for all other defeated candidates (i.e. other than the $2^{\text {nd }}$ highest vote getting candidate) increased from 2008 to 2013. The increase in the competitiveness of elections from 2008 to 2013 can be attributed to the fact that in 2008 the Congress party was in a coalition with TMC at the state level but fought the local government elections separately in 2013.

In Table 7, we compare NREGS outcomes and village level characteristics between the ruling party village (where GP level ruling party is the winning party) and the opponent party village (where GP level ruling party is not the winning party). Though the simple comparison of village level means seems to indicate that ruling party villages have better NREGS outcomes (these being average NREGS expenditures per village, average NREGS days annually in the village and NREGS days worked per household in the village), the mean differences are statistically insignificant, suggesting that NREGS outcomes, and in particular, 
allocation of NREGS funds, does not differ between ruling party and opponent party villages within the same GP. ${ }^{2}$ We also find no clear differences in village level characteristics (such as proportion of BPL households, or proportion of village members who are females or from socially disadvantaged backgrounds) between ruling party and opponent party villages.

Table 7: NREGS outcomes and village level characteristics by ruling party and opponent party village

\begin{tabular}{llll}
\hline Variable & $\begin{array}{l}\text { Avg. value } \\
\text { in ruling } \\
\text { party village } \\
\text { (T=1) }\end{array}$ & $\begin{array}{l}\text { Avg. value } \\
\text { in opponent } \\
\text { party village } \\
\text { (T=0) }\end{array}$ & $\begin{array}{l}\text { T-stats } \\
\text { from t-test } \\
\text { for mean } \\
\text { difference. }\end{array}$ \\
\hline NREGS Expenditure & 457512.8 & 422547.9 & 0.82 \\
NREGS days Generated annually & 3780.465 & 3415.59 & 1.0323 \\
NREGS days worked per NREGS household & 32.11855 & 30.36 & 0.4821 \\
NREGS Wage & 121.2386 & 122.825 & 1.2491 \\
Average expenditure per schemes & 143901.8 & 124960.5 & $1.7028^{*}$ \\
No. of total Job Card & 260.913 & 268.5875 & 0.7110 \\
No. of active Job card & 154.1523 & 137.9208 & 1.4587 \\
2008 ruling party vote share at village in 2008 election & 57.58612 & 32.3459 & $21.129^{* * *}$ \\
Total Voters in 2008 Election & 1011.253 & 1007.204 & 0.1772 \\
Percentage of voters who cast their vote in 2008 & 86.40609 & 88.63127 & $2.95^{* *}$ \\
Total monsoon rain annually (in millimetres) & 1535.444 & 1581.955 & 0.8427 \\
No. of households & 371.5831 & 407.375 & $2.397 * *$ \\
Percentage of Below Poverty Line (BPL) households & 42.44 & 40.67 & 0.8716 \\
Percentage of Minority (Muslim, Christian) households & 4.47 & 9.98 & $4.83^{* * *}$ \\
Worker to Non-worker ratio & 0.6580254 & 0.6172715 & $4.2139^{* * *}$ \\
Percentage of male village-member 2008 & 58.79 & 62.91 & 1.038 \\
Percentage of female village-member 2008 & 41.21 & 37.09 & 1.038 \\
Percentage of General caste village-member 2008 & 45.78 & 43.75 & 0.5032 \\
Percentage of Scheduled Caste village-member 2008 & 27.71 & 31.66 & 1.0726 \\
Percentage of Scheduled village-member 2008 & 15.66 & 8.7 & $2.53^{* *}$ \\
Percentage of Other Backward Class village-member & 5.06 & 4.6 & 0.2724 \\
2008 & & & \\
Percentage of Minority caste village-member 2008 & 5.78 & 11.29 & $2.5242^{* * *}$ \\
Total Voters in 2013 & 946.6434 & 917.3083 & 1.5652 \\
Percentage of voters casted their vote in 2013 & 86.413 & 87.469 & 1.8689 \\
2008 ruling Party's vote share at village in 2013 election & 42.22 & 35.33 & $3.99^{* * *}$ \\
\hline Source: Calculation from primary pooled survey & data from 569 & Gram Sansads for $2010-2012$ \\
\end{tabular}

Do NREGS outcomes at village level differ by the party affiliation of the village level elected member? To examine this, we look at three cases: case-1, where we look at the average value of the NREGS outcome variables at the village level across different parties; case 2, where we look at only TMC ruled GPs and case-3, where we look at CPIM ruled GPs. Table 8 summarises the results.

\footnotetext{
${ }^{2}$ In the Appendix, we report two similar tables, one of which captures the same information as Table 7, with the CPIM as the ruling party (Appendix-1) and another one with TMC as the ruling party (Appendix-2). Both Appendix-1 and 2 show that irrespective of party affiliation, higher values of NREGS outcome variables were observed in ruling party villages.
} 
Table 8: Village level variation of NREGS outcomes (annual values) by party affiliation

\begin{tabular}{|c|c|c|c|c|c|c|c|}
\hline \multirow{3}{*}{$\begin{array}{l}\text { Party } \\
\text { Affiliation } \\
\text { of winning } \\
\text { member }\end{array}$} & \multirow{3}{*}{$\begin{array}{c}\text { Percentage } \\
\text { of seat after } \\
2008 \\
\text { election (In } \\
\text { study } \\
\text { villages) }\end{array}$} & \multirow{2}{*}{\multicolumn{2}{|c|}{$\begin{array}{c}\text { Case-1 } \\
\text { NREGS Outcome (in } \\
\text { Pooled GP) }\end{array}$}} & \multirow{2}{*}{\multicolumn{2}{|c|}{$\begin{array}{c}\text { Case-2 } \\
\text { NREGS Outcome (TMC } \\
\text { as GP level ruling party) }\end{array}$}} & \multirow{2}{*}{\multicolumn{2}{|c|}{$\begin{array}{c}\text { Case-3 } \\
\text { NREGS Outcome (Left } \\
\text { as GP level ruling party) }\end{array}$}} \\
\hline & & & & & & & \\
\hline & & $\begin{array}{l}\text { NREGS } \\
\text { Expenditure } \\
\text { (in INR) }\end{array}$ & $\begin{array}{c}\text { Average } \\
\text { days per } \\
\text { hh worked }\end{array}$ & $\begin{array}{l}\text { NREGS } \\
\text { Expenditur } \\
\text { e (in INR) }\end{array}$ & $\begin{array}{c}\text { Average } \\
\text { days per } \\
\text { hh worked }\end{array}$ & $\begin{array}{l}\text { NREGS } \\
\text { Expenditur } \\
\text { e (in INR) }\end{array}$ & $\begin{array}{l}\text { Average } \\
\text { days per } \\
\text { hh worked }\end{array}$ \\
\hline TMC & 32.98 & 461269.4 & 39.98 & 595593.7 & 50.75 & 257253.8 & 25.54 \\
\hline Left & 52.37 & $\begin{array}{l}403762 \\
(1.87)^{*}\end{array}$ & $\begin{array}{c}25.59 \\
(3.89)^{* * *}\end{array}$ & $\begin{array}{l}316900.8 \\
(2.20)^{* *}\end{array}$ & $\begin{array}{l}32.75 \\
(1.52)\end{array}$ & $\begin{array}{c}419145.9 \\
(2.91)^{* *}\end{array}$ & $\begin{array}{l}27.72 \\
(0.55)\end{array}$ \\
\hline Congress & 9.92 & $\begin{array}{c}659454.3 \\
(0.98)\end{array}$ & $\begin{array}{l}38.76 \\
(0.58)\end{array}$ & $\begin{array}{c}924633.7 \\
(0.67)\end{array}$ & $\begin{array}{l}106.16 \\
(0.82)\end{array}$ & $\begin{array}{c}601747.4 \\
(0.76)\end{array}$ & $\begin{array}{l}20.48 \\
(0.88)\end{array}$ \\
\hline Others & 4.73 & $\begin{array}{c}331942.5 \\
(0.37)\end{array}$ & $\begin{array}{l}21.99 \\
(0.38)\end{array}$ & - & - & $\begin{array}{c}358006.3 \\
(0.48)\end{array}$ & $\begin{array}{l}22.92 \\
(0.77)\end{array}$ \\
\hline Overall & 100 & 444701.2 & 31.47 & 567248.7 & 51.93 & $\begin{array}{c}398873.6 \\
(3.49)^{* *}\end{array}$ & $\begin{array}{c}25.39 \\
(6.57)^{* * *}\end{array}$ \\
\hline
\end{tabular}

Source: Authors' calculation from primary survey.

Note: Values in the bracket show the value of t-statistics of t-test for mean difference of that respective mean value and corresponding mean value in TMC village or TMC GP.

From Table 8, under case-1 when we consider all the GPs in our sample, we can see that village wise average NREGS expenditure and average NREGS days worked by a NREGS household in TMC villages are higher compared to Left villages, and these differences are statistically significant. These values are also higher in Congress villages as compared to TMC villages but these differences are not statistically significant. We find both NREGS outcomes have much higher values in TMC villages compared to Left villages when TMC is the ruling party at the GP level (case 2), and are statistically significant. In Congress villages when TMC is the ruling party, NREGS outcomes are also better but the results are based on very fewnumber of cases. ${ }^{3}$ When the LF is the ruling party at the GP level, the average values of NREGS outcome variables are higher in Left villages compared to TMC villages, and these differences are statistically significant (case 3). However, in Congress villages under Left ruled GPs, NREGS outcomes are better compared to Left villages but such differences are not statistically significant. Finally, when we compared the village level values of NREGS outcomes between TMC ruled GP and Left ruled GP, we find annual average NREGS expenditure in a village under TMC GP is INR 567248.7 and that in Left ruled GP is INR 398873.6 and this difference is statistically significant. We obtain a similar set of results if we use the average NREGS days worked by a representative NREGS household at the village level as our measure of NREGA outcomes.

\footnotetext{
${ }^{3}$ There were only a small number of cases where the candidate from the Congress was the winning candidate at the village level when TMC was the ruling party at the GP level.
} 
To summarise, Table 8 shows a general pattern that constituencies won by ruling parties tend to exhibit higher values of NREGS outcomes as compared to opponent party constituencies and this trend holds across two major competing political parties in West Bengal. This does not necessarily allow us to infer the presence of partisan alignment in our data since the cause of positive discrimination of NREGS funds towards ruling party villages may be explained by other village level covariates other than the fact that the village is a ruling party village. In the next section, we propose a quasi-experimental method - fuzzy regression discontinuity design - to trace the causal effect of a village under the control of the ruling party observing better NREGS outcomes.

\section{Empirical Strategy}

This study addresses two related questions. The first question we address is whether ruling parties in village councils favour their own constituencies in terms of NREGS outcomes as compared to opponent party constituencies. We call this the ruling party treatment effect or alignment effect. The second question is whether ruling parties increase their electoral performance in the next election by favouring their own constituencies over opponent constituencies. We call this the ruling party feedback effect.

To address the first question, we use a regression discontinuity (RD) approach. This is the first stage of our econometric analysis. The RD strategy exploits the facts that ruling party candidate's winning probability at the village level changes discontinuously at a particular threshold of the proportion of ruling party's vote share at the village level. Villages where the ruling party wins by a large margin are likely to be different from villages where the ruling party loses by a wide margin. By narrowing our focus on the set of villages with close elections, it becomes more plausible that election outcomes are determined by idiosyncratic factors and not by systematic village level characteristics that could also affect NREGS outcomes. To address the second question, we use an Indirect Least Squares approach that uses the predicted NREGS outcome we obtain from the first stage RD strategy as our core explanatory variable to test for feedback effects. This is the second stage of the econometric analysis. By using only that part of NREGS outcomes in a given village which is due to the ruling party treatment effect, we net out any other factor that may be responsible for allocation of NREGS funds to that village (such as an increase in demand for NREGS employment in the village). Our strategy allows us to isolate the effects of partisan alignment on electoral performance of the ruling party in the next election from other confounding factors. We explain next in greater detail the estimation methods we followed in the first and second stages. 


\section{Estimation Method for the First Stage}

We use a fuzzy RD design as with many parties contesting elections in village councils in West Bengal in the period of our study, parties could win power even if they have not won more than 50 per cent of the votes (which could be the case if only two political parties competed for power). This is clear from Figure 3, which graphically examines the relationship between the GP level ruling party's vote share at village level and the ruling party's winning probability at the village level. On the horizontal axis we plot the vote share of GP level ruling party at the village level and in the vertical axis we plot the winning probability of GP level ruling party at the village level i.e. probability of $\mathrm{T}=1$ i.e. $\mathrm{P}(\mathrm{T}=1)$. Here $\mathrm{T}$ is a treatment dummy which is 1 if the GP level ruling party is also a winning party at village level and 0 otherwise. By construction $0 \leq \mathrm{P}(\mathrm{T}=1) \leq 1$. Each point on the graph represents the mean value of y-variables (measured in the vertical axis) within a band of ruling party's vote share at village with a band width of 2.5 .

We see that if a party obtains close to $25 \%$ vote share, $\mathrm{P}(\mathrm{T}=1)$ (i.e. ruling party's winning probability at the village level) is above zero, and it increases as ruling party's vote share increases. For instance, around the band of $40-42.5 \%$ (or $45-47.5 \%$ ) of vote share of the ruling party, the probability of winning is around 0.5 . Once the ruling party's vote share crosses $50 \%$ the ruling party's winning probability at the village level is 1 . The gradual increase in the probability of winning as vote share increases from 25 per cent to 50 per cent, followed by a sharp discontinuity when the vote share crosses 50 per cent justifies the use of a fuzzy design rather than a sharp design RD strategy.

Figure 3: Ruling party's vote share and winning/treatment probability at the village level.

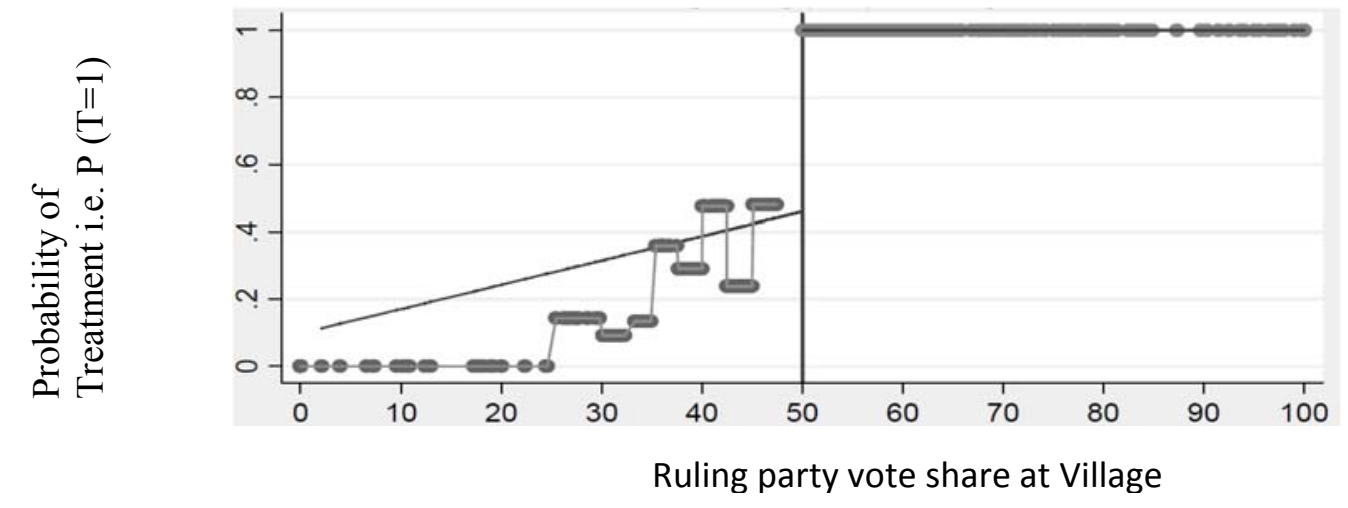

We now provide a formal exposition of the fuzzy regression discontinuity design (FRDD) we use in the empirical analysis. 


\section{Identifying the Treatment Effect under Imperfect Compliance through the FRDD}

The basic idea of RD design is that the probability of receiving a treatment (i.e. a village being a GP level ruling party's village) is a discontinuous function of a continuous treatment determining variable (i.e. X= GP level ruling party's vote share at the village). However, treatment in our case does not change from 0 to 1 at the cut-off point (i.e. $X=50$ ). In our case treatment will be 1 for $\mathrm{X}>50$ (perfect compliance) but for $\mathrm{X}<=50$ treatment may not necessarily be 0 (imperfect compliance). In such a case FRDD is appropriate because it allows for a smaller jump (less than one) in the probability of treatment at the cut-off. In case of a binary treatment FRDD design may be seen as a Wald estimator (around the discontinuity c) and the treatment effect can be written as

$$
\sigma_{F R D}=\frac{\lim _{\varepsilon \downarrow 0} E[Y \mid X=c+\varepsilon]-\lim _{\varepsilon \uparrow 0} E[Y \mid X=c+\varepsilon]}{\lim _{\varepsilon \downarrow 0} E[T \mid X=c+\varepsilon]-\lim _{\varepsilon \uparrow 0} E[T \mid X=c+\varepsilon]}
$$

where, in our case, $\mathrm{c}$ is the cut-off point; $\mathrm{X}$ is the GP level ruling party vote share at village; $\mathrm{T}$ is the treatment. In the following sub-section, we explain how we can estimate $\sigma$ using Two Stage Least Square or IV estimation technique

\section{Estimation Strategies for the Local Treatment Effect under FRDD}

In this study, the outcome denoted by $\mathrm{Y}$ is the village-wise NREGS expenditure. T denotes a binary treatment variable taking 1 if the village-level winning candidate belongs to GP level ruling party and 0 if he or she does not belong to GP level ruling party. After normalising ' $X$ ' into ' $X$ ', where $X=(\mathrm{X}-50)$, the cut-off is at $X=0$. Potential outcome can be written in the following structural form equation (Angrist and Pischke, 2009):

$$
Y=f(x)+\sigma T+e
$$

where $\sigma$ denotes the local average treatment effect on Y. This is estimated in FRDD by extrapolating the compliance group (Imbens and Angrist, 1994), and:

$$
Y= \begin{cases}Y_{1}=f_{1}(x)+\sigma+e & \text { if } \mathrm{T}=1 \\ Y_{0}=f_{0}(x)+e & \text { if } \mathrm{T}=0\end{cases}
$$

Where, $Y_{0}$ denotes the potential outcome i.e. village-wise NREGS expenditure that is explained by $\mathrm{X}$ in $f_{0}(x)$ and other (observed and unobserved) covariates in the error term denoted by e. In other words, $Y_{0}$ is the village-wise NREGS expenditure in non-ruling party 
villages and $Y_{1}$ is the potential outcome i.e. village wise NREGS expenditure with treatment i.e. village wise NREGS expenditure in ruling party's villages, where $\sigma$ is added with $Y_{0}$.

The conditional probability of treatment $\mathrm{P}(\mathrm{T}=1 \mid X)$ is expected to be discontinuous at the cutoff, $X=0$. Thus, it can be written in the following form:

$$
\mathrm{P}(\mathrm{T}=1 \mid x)=\mathrm{E}(\mathrm{T} \mid x)= \begin{cases}g_{1}(x) & \text { if } x>=0 \\ g_{0}(x) & \text { if } x<0\end{cases}
$$

where, $g_{1}(0)>g_{0}(0)$ indicates discontinuity in $\mathrm{P}(\mathrm{T}=1 \mid x)$ at $x=0$. Now $\mathrm{E}(\mathrm{T} \mid x)$ can be written in the following functional form:

$\mathrm{E}(\mathrm{T} \mid x)=g_{0}(x)+\left[g_{1}(x)-g_{0}(x)\right] \mathrm{Z}=g_{0}(x)+\pi \mathrm{Z}$

Where, $g_{1}(x)-g_{0}(x)=\pi$ and $Z$ is an instrumental variable for endogenous treatment variable T. Z determines the eligibility of village to be a treated village (i.e. ruling party's village) or non-treated village (i.e. non-ruling party's village). Thus, $\mathrm{Z}$ is constructed as follows

$$
Z=\left\{\begin{array}{l}
1 \text { if } x>0 \\
0 \text { if } x<=0
\end{array}\right.
$$

Thus treatment equation for $\mathrm{T}$ can be written as

$\mathrm{T}=g_{0}(x)+\pi \mathrm{Z}+\xi$

Where, coefficient of $z$ that is $\pi$ will capture the jump in the probability of treatment at the cut-off.

In Equation 6, $\xi$ denotes an error term that captures observed and unobserved factors plus measurement error in $X$ influencing T. Equation (6) is a reduced form equation, while Equation (2) is a structural one. From Equation (2), the local average treatment effect (i.e. effect on $\mathrm{Y}$ of being a ruling party ward), $\sigma$, is not identified as $\mathrm{E}(\mathrm{T}, \mathrm{e}) \neq 0$, which indicates that $\mathrm{T}$ is an endogenous variable.

The treatment effect ' $\sigma$ ' can be identified applying either indirect least squares (ILS) or two stage least squares (2SLS). Under ILS, we need to substitute Equation (6) into Equation (2). After doing this, we have the following reduced form equation of outcome variable Y: 
$\left.\begin{array}{l}Y=f(x)+\sigma\left\{\mathrm{g}_{0}(x)+\pi \mathrm{Z}+\xi\right\}+e \\ =f(x)+\sigma \mathrm{g}_{0}(x)+\sigma \pi \mathrm{Z}+\sigma \xi+e \\ =k(x)+\sigma \pi \mathrm{Z}+\psi\end{array}\right\}$

where $f(x)+\sigma_{0}(x)=k(x)$ and $\sigma \xi+e=\psi$. Now we can estimate the local average treatment effect $\sigma$, dividing $\sigma \pi$, the co-efficient of $\mathrm{Z}$ in Equation (7), by $\pi$, the co-efficient of $\mathrm{Z}$ in equation (6). However, in this paper we followed 2SLS or IV regression.

We run IV or 2SLS regression as:

$$
Y=f_{0}(x)+\sigma E(T \mid x)+e
$$

where the coefficient at $\mathrm{E}(\mathrm{T} \mid x), \sigma$, is the local average treatment effect of compliers, and $\mathrm{E}(\mathrm{T} \mid X)$ comes from Equation (6), which can be treated as the first stage regression of IV (or 2SLS).

Following Lee and Lemieux's (2009) suggestion, we estimate the parameter of interest $\sigma$ using two different methods. The first one is based on a local linear regression around the discontinuity choosing the optimal bandwidth in a cross validation procedure that we discuss in Appendix 3. The second method makes use of the full sample using a polynomial regression in which the equivalent of the bandwidth choice is the choice of the correct order of the polynomial by using AI (Akaike Information) Criterion (see Appendix 4). In both cases, we estimate the treatment effect using 2SLS which is numerically equivalent to computing the ratio (as illustrated in Equation 1) in the estimated jump (at the cut-off point) in outcome variable over the jump in the probability of treatment, provided that the same bandwidth or same polynomial order is used for both equations. This allows us to obtain directly the correct standard errors that are robust and clustered at the village level.

Our assignment variable $\mathrm{X}$ (which after normalisation is $X=\mathrm{X}-50$ ) which shows the GP level ruling party's vote share in each village is constructed on the basis of the GP election results from 2008 election. The outcome variable(Y) is from the village level pooled panel data on NREGS implementation from 2010 to 2012 and other village level covariates are also from 2010 to 2012. In Online Appendix A2, we discuss in details all the identification issues related to the FRDD method and test for the validity of RD design. 


\section{Estimation Method for the Second Stage}

To estimate the effect of partisan alignment on electoral performance of the ruling party in the subsequent election, we use an indirect least square estimation method. As we noted previously, $\sigma$ captures the treatment effect in Equation 8. This allows us to derive the estimate of $Y$ from Equation 8, where the predicted value of $Y$ (say, $Y$ hat) for $T=1$ for each village will capture that part of $\mathrm{Y}$ which is explained by the ruling party-treatment effect. In this case, $\mathrm{Y}-\mathrm{Y} \_$hat will show the value of $\mathrm{Y}$ which is explained by other observed and unobserved factors. We use $\mathrm{Y}_{-}$hat as our main explanatory variable to estimate the 2008 ruling party's vote share in 2013 election. The empirical specification to estimate the electoral gains to partisan alignment is the following.

$$
V_{i_{-} 2013}=\alpha_{0}+\alpha_{1} Y_{-} h a t+\gamma K+d+\varepsilon_{i}
$$

where $V_{i_{-} 2013}$ is the 2008 ruling party's vote share in 2013 panchayat election at village i, $Y_{-}$hat is the predicted value of $\mathrm{Y}$ for $\mathrm{T}=1$ from Equation 8 and $\mathrm{K}$ is the vector of other village level characteristics that may explain election outcomes, ' $d$ ' is the district fixed effect and $\varepsilon_{i}$ is the unobserved error. We use the percentage of winning margin to total votes casted in 2008 election, percentage of votes received by all other contesting candidates excluding the total votes of $1^{\text {st }}$ and the $2^{\text {nd }}$ placed candidate in the 2008 election as controls for the extent of political competition in the village. We also include number of households, percentage of below poverty line (BPL) households, percentage of minority households, and the worker to non-worker ratio as village characteristics that may affect election outcomes (poorer households or households that belong to certain social groups may consistently vote for one party over another).

We are particularly interested to see the sign, magnitude and statistical significance of $\alpha_{1}$. Equation 9 will be estimated by using the Ordinary Least Square (OLS) estimation technique. ${ }^{4}$ As a robustness test, we will also use the probability of the 2008 ruling party getting re-elected in 2013 election as an alternate left-hand side variable (where the dependent variable is 1 if the ruling party gets re-elected and 0 otherwise). In this case, we will use probit regression instead of OLS.

${ }^{4}$ It should be noted that in Equation 9 we use $Y \_$hat instead of $Y$ to deal with the endogeneity associated with $Y$. 


\section{Results}

In this section, we present the results of our first stage empirical analysis (the ruling party treatment effect), followed by the results of our second stage empirical analysis (the ruling party feedback effect).

\section{Results for Ruling Party Treatment Effect}

We first present some graphical evidence of the presence of the ruling party treatment effect before presenting the main results from the FRDD estimation. First, in Figure 4, we look at the GP level ruling party's vote share at each village and value of NREGS outcome variables at each village without specifying the ruling party. We can see from the figure that in respect of both the NREGS outcome variables, as the GP level ruling party's village level vote share crosses 50 per cent, there is a positive discontinuous shift in the value of the outcome variables.

Figure 4: Effect of Any Party being GP level Ruling Party on village level NREGS Outcomes
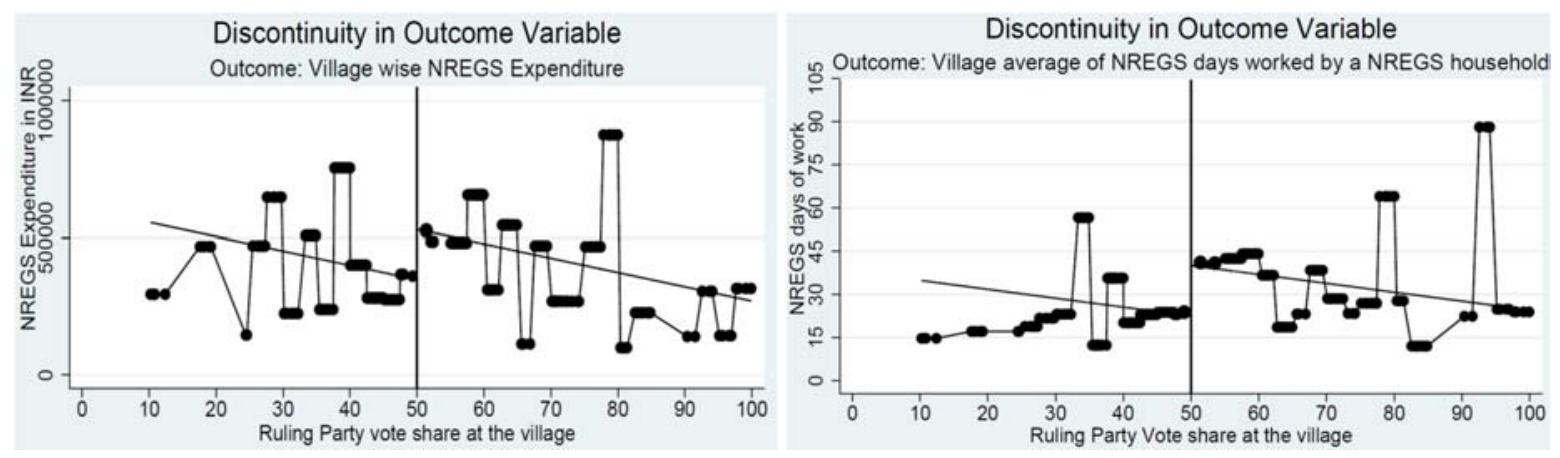

In Figure 5 we perform the same previous exercise but this time only for TMC ruled GPs. On the vertical axis we measure the village level values of NREGS outcome variables, and on the horizontal axis, we plot TMC's vote share at the village level. From Figure 5, we see that as TMC party's village level vote share crosses $50 \%$ there is a positive discontinuous jump in the values of outcome variables. 
Figure 5: Effect of TMC being GP level Ruling Party on village level NREGS Outcomes
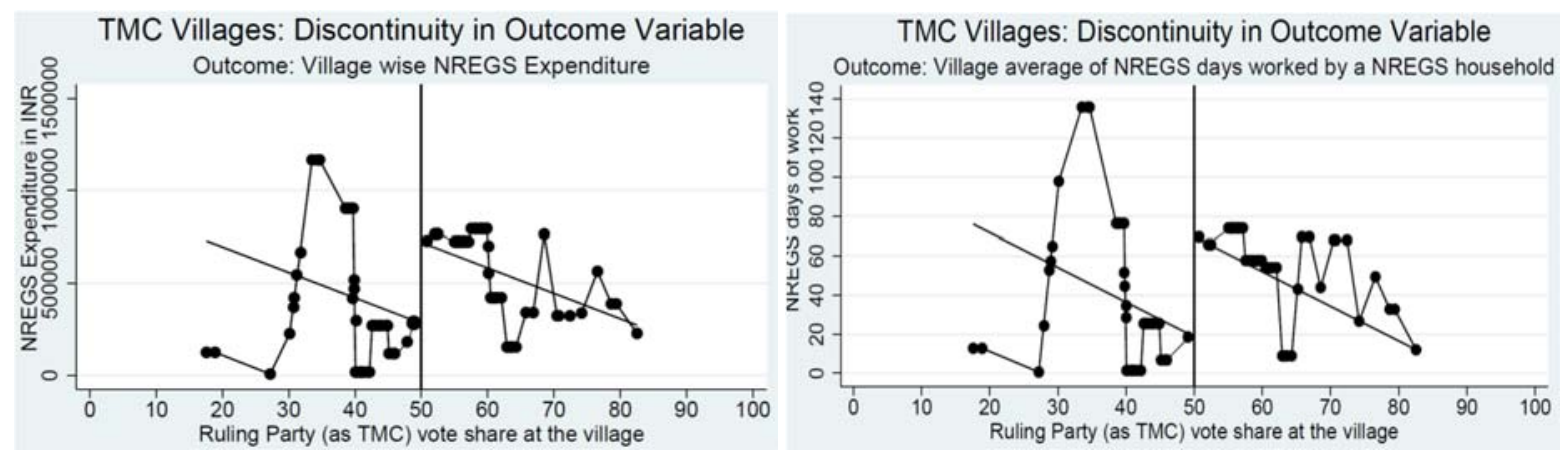

In Figure 6 we do the same exercise with CPIM as the GP level ruling. We do not see any discontinuity around the cut-off as we did in Figures 4 and 5.

Figure 6: Effect of CPIM being GP level Ruling Party on village level NREGS Outcomes
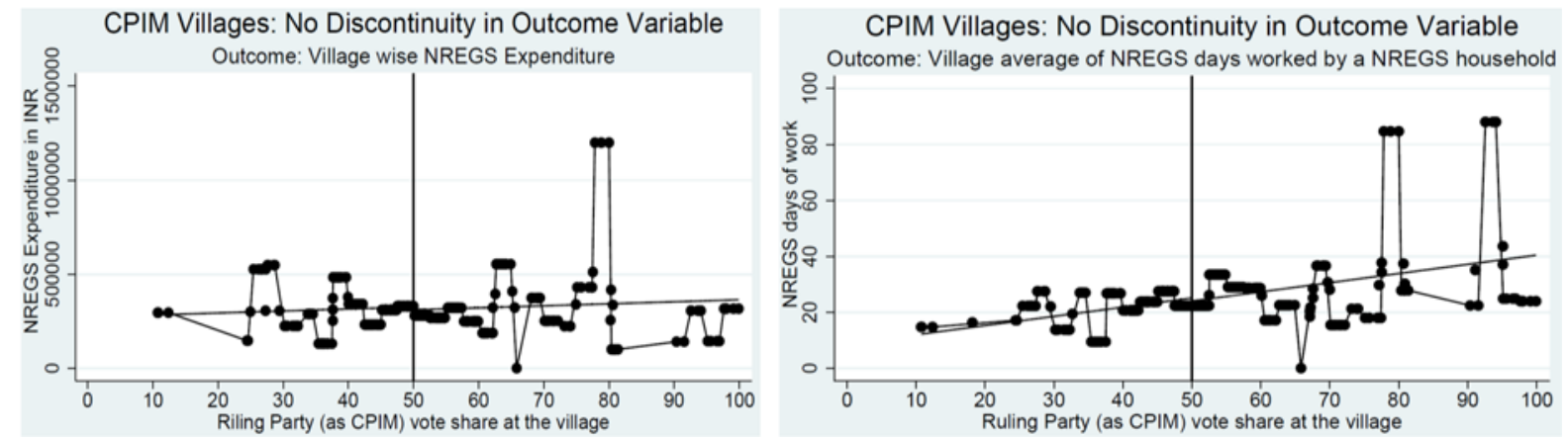

\section{Results for the Ruling Party Treatment Effect}

We start by presenting the estimated treatment effect i.e. the effect of 'being a ruling party winning candidate at the village level' on NREGS outcomes -village wise NREGS expenditure and average NREGS days of work by a household in the village - using local linear regression. In Appendix 3, we discuss the cross-validation procedure suggested by Imbens and Lemieux (2008) for choosing the optimal bandwidth. This procedure results in an optimal bandwidth that is calculated to be 5 on both sides of the discontinuity for estimating the treatment effect on the outcome variable. However, we also explore the sensitivity of the results to a range of bandwidth (as $\mathrm{h}$ ) that goes from 5 to 10 around the discontinuity $X=0$ or $X=50$.

Tables 9 and 10 show the estimated treatment effect (i.e. $\hat{\sigma}$ ) on our two NREGS outcomes respectively at the village level, along with the estimated jump in the probability of treatment $(\hat{\pi})$ from the first stage of 2SLS or IV regression. For both Table 9 and 10, the results are shown for 3 different samples. First, we present the results based on the whole sample covering all the GPs in the sample without specifying which party is the ruling party at the 
GP level. The second set of results is based on a sub-sample of GPs where we only considered TMC ruled GPs. The third set of the results are based on a sub-sample of GPs where we only considered CPIM ruled GPs. The last row of each table reports the first stage F-test on the excluded instrument (i.e. Z)- the dummy variable indicating the effect of the treatment.

Focusing on the results with optimal bandwidth (i.e. 5), we observe that treatment effect is INR 38749.8 when we use the whole sample. In other words, if a village is a ruling party's winning village that village receives INR 38749.8 more in terms of NREGS expenditure compared to a non-ruling party's village and this result is statistically significant at $1 \%$ level. However, this treatment effect gets more pronounced when we run the results only within TMC GPs. It is evident from Table 9 that when TMC is the ruling party they tend to spend INR 125253.6 more funds in their own village or constituency compared to opponent's village and this result is also statistically significant at 1 per cent level. It is interesting to note that when we run our results only within CPIM GPs the sign of the treatment effect is negative which implies when CPIM is the ruling party, they tend to spend less in their own villages. However, the treatment co-efficient is statistically insignificant.

It is also important to note that the treatment effect is robust to a change in bandwidth as the sign and significance remain almost identical across different bandwidths. In all these cases, there is a significant jump in the probability of treatment which is evident from the first stage of the 2SLS or IV regression and captured in terms of $\hat{\pi}$. One important observation to make here that in all these cases, the jump in the estimated probability of treatment is much less than 1 and rather this is around 0.50. This is essentially supports our fuzzy RD design and Figure 3.

Table10 shows similar results with a different outcome variable. Here we use 'average days of NREGS work availed by a household at the village level'. From the table we find that the direction of treatment remains exactly same as with Table 9. When we run the results with the whole sample of GP we obtain a small treatment effect i.e. households in the ruling party's village receive 3.59 days more of NREGS work compared with the households in the non-ruling party's village. However, when we run the result in the TMC GPs then we can see households in the TMC villages receive 13.702 days more of NREGS work than the households in the non-TMC villages within the same GP. Both these results are statistically significant and robust with the change in the bandwidth. The results for the CPIM GPs show households in the CPIM villages get less days of work compared with non-CPIM villages within the same GP, but this negative treatment effect is also statistically insignificant. 
Table 9: Treatment effect on village-wise expenditure (Local Linear Regression)

\begin{tabular}{|c|c|c|c|c|c|c|}
\hline \multicolumn{7}{|c|}{ From whole sample of GP } \\
\hline & $\mathrm{h}=10$ & $\mathrm{~h}=9$ & $\mathrm{~h}=8$ & $\mathrm{~h}=7$ & $\mathrm{~h}=6$ & $\mathrm{~h}=5$ \\
\hline Jump in probability of treatment $(\hat{\pi})$ & $\begin{array}{c}0.426^{* * *} \\
(6.56)\end{array}$ & $\begin{array}{c}0.425^{* * *} \\
(7.31)\end{array}$ & $\begin{array}{c}0.436^{* * *} \\
(7.67)\end{array}$ & $\begin{array}{c}0.472 * * * \\
(3.06)\end{array}$ & $\begin{array}{c}0.449 * * * \\
(4.84)\end{array}$ & $\begin{array}{c}0.479^{* * *} \\
(9.50)\end{array}$ \\
\hline Treatment Effect $(\hat{\sigma})$ & $\begin{array}{c}26394.42 \\
(1.01) \\
\end{array}$ & $\begin{array}{c}32139.11 \\
(1.35) \\
\end{array}$ & $\begin{array}{c}37265.5^{* *} \\
(2.09) \\
\end{array}$ & $\begin{array}{c}32605.9^{*} \\
(1.77) \\
\end{array}$ & $\begin{array}{c}32989.57^{*} \\
(1.90) \\
\end{array}$ & $\begin{array}{c}38749.8^{* * *} \\
(2.65) \\
\end{array}$ \\
\hline $\mathrm{N}$ & 573 & 553 & 517 & 490 & 474 & 457 \\
\hline F-test & 42.97 & 53.39 & 58.83 & 71.89 & 75.75 & 90.19 \\
\hline \multicolumn{7}{|c|}{ From sub sample with only TMC GPs (i.e. TMC is the ruling Party) } \\
\hline Jump in probability of treatment $(\hat{\pi})$ & $\begin{array}{c}0.562 * * * \\
(6.25)\end{array}$ & $\begin{array}{c}0.564 * * * \\
(6.23)\end{array}$ & $\begin{array}{c}0.513 * * * \\
(5.07)\end{array}$ & $\begin{array}{c}0.506 * * * \\
(4.75)\end{array}$ & $\begin{array}{c}0.518 * * * \\
(4.71)\end{array}$ & $\begin{array}{c}0.501 * * * \\
(4.12)\end{array}$ \\
\hline Treatment Effect $(\hat{\sigma})$ & $\begin{array}{c}61935^{* *} \\
(2.23)\end{array}$ & $\begin{array}{c}70328.21^{* *} \\
(2.33)\end{array}$ & $\begin{array}{c}83093.85^{* *} \\
(2.21)\end{array}$ & $\begin{array}{c}103427.3^{* *} \\
(2.29)\end{array}$ & $\begin{array}{c}108499.1^{* * * *} \\
(2.88)\end{array}$ & $\begin{array}{c}125253.6^{* * * *} \\
(2.66)\end{array}$ \\
\hline $\begin{array}{c}\mathrm{N} \\
\text { F-test }\end{array}$ & $\begin{array}{c}156 \\
39.08 \\
\end{array}$ & $\begin{array}{c}150 \\
38.84 \\
\end{array}$ & $\begin{array}{c}144 \\
25.73 \\
\end{array}$ & $\begin{array}{c}138 \\
22.53 \\
\end{array}$ & $\begin{array}{c}132 \\
22.21 \\
\end{array}$ & $\begin{array}{c}121 \\
16.93 \\
\end{array}$ \\
\hline \multicolumn{7}{|c|}{ From sub sample with only Left GPs (i.e. Left is the ruling Party) } \\
\hline Jump in probability of treatment $(\hat{\pi})$ & $\begin{array}{c}0.421^{* * *} \\
(9.28)\end{array}$ & $\begin{array}{c}0.404 * * * \\
(8.01)\end{array}$ & $\begin{array}{c}0.436^{* * *} \\
(6.84)\end{array}$ & $\begin{array}{c}0.450^{* * *} \\
(6.24)\end{array}$ & $\begin{array}{c}0.321 * * * \\
(4.28)\end{array}$ & $\begin{array}{c}0.317 * * * \\
(3.96)\end{array}$ \\
\hline Treatment Effect $(\hat{\sigma})$ & $\begin{array}{c}-16113.87 \\
(1.38)\end{array}$ & $\begin{array}{c}-27902.66 \\
(0.05)\end{array}$ & $\begin{array}{c}-17439.02 \\
(1.28)\end{array}$ & $\begin{array}{c}-20343.15 \\
(1.34)\end{array}$ & $\begin{array}{c}-21287.08 \\
(0.19)\end{array}$ & $\begin{array}{c}-21108.5 \\
(0.98)\end{array}$ \\
\hline $\begin{array}{c}\mathrm{N} \\
\text { F-test }\end{array}$ & $\begin{array}{c}356 \\
86.14\end{array}$ & $\begin{array}{c}342 \\
64.14\end{array}$ & $\begin{array}{c}320 \\
46.74\end{array}$ & $\begin{array}{c}300 \\
38.98\end{array}$ & $\begin{array}{c}264 \\
18.31\end{array}$ & $\begin{array}{c}246 \\
15.68\end{array}$ \\
\hline
\end{tabular}

Table-10: Treatment effect on village level days of NREGS work by per household (Local Linear Regression)

\begin{tabular}{|c|c|c|c|c|c|c|}
\hline \multicolumn{7}{|c|}{ From whole sample } \\
\hline & $\mathrm{h}=10$ & $\mathrm{~h}=9$ & $\mathrm{~h}=8$ & $\mathrm{~h}=7$ & $h=6$ & $\mathrm{~h}=5$ \\
\hline Jump in probability of treatment $(\hat{\pi})$ & $\begin{array}{c}0.426^{* * *} \\
(6.56)\end{array}$ & $\begin{array}{c}0.425 * * * \\
(7.31)\end{array}$ & $\begin{array}{c}0.436 * * * \\
(7.67)\end{array}$ & $\begin{array}{c}0.472 * * * \\
(3.06)\end{array}$ & $\begin{array}{c}0.449 * * * \\
(4.84)\end{array}$ & $\begin{array}{c}0.479 * * * \\
(9.50)\end{array}$ \\
\hline Treatment $\operatorname{Effect}(\hat{\sigma})$ & $\begin{array}{c}2.507 * * \\
(2.30)\end{array}$ & $\begin{array}{c}3.328 * * * \\
(2.84)\end{array}$ & $\begin{array}{c}4.017 * * * \\
(2.75)\end{array}$ & $\begin{array}{c}3.656^{* *} \\
(2.49)\end{array}$ & $\begin{array}{c}3.636^{* *} \\
(2.21)\end{array}$ & $\begin{array}{c}3.596^{* *} \\
(2.04)\end{array}$ \\
\hline $\begin{array}{c}\mathrm{N} \\
\text { F-test }\end{array}$ & $\begin{array}{c}573 \\
42.97\end{array}$ & $\begin{array}{c}553 \\
53.39\end{array}$ & $\begin{array}{c}517 \\
58.83\end{array}$ & $\begin{array}{c}490 \\
71.89\end{array}$ & $\begin{array}{c}474 \\
75.75\end{array}$ & $\begin{array}{c}457 \\
90.19\end{array}$ \\
\hline \multicolumn{7}{|c|}{ From sub sample with only TMC GPs (i.e. TMC is the ruling Party) } \\
\hline Jump in probability of treatment $(\hat{\pi})$ & $\begin{array}{c}0.562 * * * \\
(6.25)\end{array}$ & $\begin{array}{c}0.564 * * * \\
(6.23)\end{array}$ & $\begin{array}{c}0.513 * * * \\
(5.07)\end{array}$ & $\begin{array}{c}0.506^{* * *} \\
(4.75)\end{array}$ & $\begin{array}{c}0.518 * * * \\
(4.71)\end{array}$ & $\begin{array}{c}0.501 * * * \\
(4.12)\end{array}$ \\
\hline Treatment $\operatorname{Effect}(\hat{\sigma})$ & $\begin{array}{c}7.142 * * * \\
(2.88) \\
\end{array}$ & $\begin{array}{c}7.988^{* * *} \\
(2.94) \\
\end{array}$ & $\begin{array}{c}9.708 * * * \\
(2.76) \\
\end{array}$ & $\begin{array}{c}12.370^{* * *} \\
(2.81)\end{array}$ & $\begin{array}{c}11.572 * * \\
(2.58) \\
\end{array}$ & $\begin{array}{c}13.702 * * \\
(1.93)\end{array}$ \\
\hline $\begin{array}{c}\mathrm{N} \\
\text { F-test }\end{array}$ & $\begin{array}{c}156 \\
39.08\end{array}$ & $\begin{array}{c}150 \\
38.84\end{array}$ & $\begin{array}{c}144 \\
25.73\end{array}$ & $\begin{array}{c}138 \\
22.53\end{array}$ & $\begin{array}{c}132 \\
22.21\end{array}$ & $\begin{array}{c}121 \\
16.93\end{array}$ \\
\hline \multicolumn{7}{|c|}{ From sub sample with only Left GPs (i.e. Left is the ruling Party) } \\
\hline Jump in probability of treatment $(\hat{\pi})$ & $\begin{array}{c}0.421 * * * \\
(9.28)\end{array}$ & $\begin{array}{c}0.404 * * * \\
(8.01)\end{array}$ & $\begin{array}{c}0.436^{* * *} \\
(6.84)\end{array}$ & $\begin{array}{c}0.450^{* * *} \\
(6.24)\end{array}$ & $\begin{array}{c}0.321 * * * \\
(4.28)\end{array}$ & $\begin{array}{c}0.317 * * * \\
(3.96)\end{array}$ \\
\hline Treatment $\operatorname{Effect}(\hat{\sigma})$ & $\begin{array}{l}-4.83 \\
(0.51)\end{array}$ & $\begin{array}{l}-2.97 \\
(0.32)\end{array}$ & $\begin{array}{l}-0.089 \\
(0.01)\end{array}$ & $\begin{array}{l}-1.98 \\
(0.17)\end{array}$ & $\begin{array}{l}-1.18 \\
(0.44)\end{array}$ & $\begin{array}{l}-0.54 \\
(0.03)\end{array}$ \\
\hline $\begin{array}{c}\mathrm{N} \\
\text { F-test }\end{array}$ & $\begin{array}{c}356 \\
86.14\end{array}$ & $\begin{array}{c}342 \\
64.14\end{array}$ & $\begin{array}{c}320 \\
46.74\end{array}$ & $\begin{array}{c}300 \\
38.98\end{array}$ & $\begin{array}{c}264 \\
18.31\end{array}$ & $\begin{array}{c}246 \\
15.68\end{array}$ \\
\hline
\end{tabular}

Note: Significance levels: * 10\%level, ** 5\% level, *** 1\% level. In the above table ' $h$ 'denotes bandwidth selection from 10 to 5 and this is in terms of $\mathrm{x}$ i.e. $\mathrm{X}-50$, where $\mathrm{X}$ is the ruling party's vote share at the village level. $|\mathrm{t}|$-stat value is in the bracket. F-test shows the Fstat value from F-test on the excluded instrument from the first stage of $2 \mathrm{SLS}$ or IV. 
To check the robustness of our results, we estimate the treatment effect on the village level NREGS outcome using polynomial regression instead of local linear regression as above. The results and discussions from this polynomial regression along with the results from the different identification tests for the validity of the FRDD design are also presented in online appendices A1, A2 and A3 respectively. We also check the sensitivity of the treatment effect with inclusion of all covariates with local linear regression (Appendix 5, Tables 5A and 5B).

\section{Estimation Results on Ruling Party Feedback Effect}

We now present the results of the second stage of the empirical analysis, where we examine the feedback effect of partisan alignment (or its absence) on 2013 election outcomes. Before presenting the regression results, we refer to Appendix 6, Table 6A, where we present the descriptive statistics on the village (or ward) level vote share of two major parties - TMC and CPIM - after the 2008 and 2013 Panchayat elections by GP level Ruling Party and by Ruling Party Treatment Effect. It is interesting to note from Table 6A that after the 2008 elections where TMC was the ruling party at the GP level and also the winning party at the village level within these GPs, the TMC improved their vote share from 55 per cent in 2008 to 62.3 per cent in 2013. On the other hand, after the 2008 elections in which CPIM was the ruling party at the GP level and also the winning party at the village level within those GPs, the party suffered a fall in their vote share from 61.8 per cent in 2008 to 34.9 per cent in 2013. More interestingly, in the constituencies where the TMC was the losing party in 2008, the TMC improved their vote share from 12.5 per cent in 2008 to 34 per cent in 2013. One explanation of this could be that in these constituencies, as the CPIM did not engage in partisan alignment, voters did not support them to the same extent in 2013. On the other hand, although TMC was a losing party in 2008 in these constituencies, it increased its vote share in 2013 out of voters' dissatisfaction in CPIM villages under a CPIM GP. However, the increase in the vote share of the TMC could also be a reflection of the swing in votes in their favour across the state.

To disentangle the electoral effect of partisan alignment from an across the board improvement in TMC's electoral performance in 2013, we attempt to find out to what extent the gain in the vote share of TMC can be attributed to the treatment effect, following the methodology outlined in the previous section.

We know from the previous set of results that the treatment effect in TMC GPs is positive and significant and the treatment effect in CPIM GPs is negative but insignificant. In our formulation $Y \_$hat represents that part of $\mathrm{Y}$ which can be explained by the treatment effects only, and we assess whether it has any feedback on election outcomes in 2013. 
Table 11: Feedback Effect on Ruling Party's Vote Share in 2013 Election

\begin{tabular}{|c|c|c|c|c|c|c|}
\hline & $\begin{array}{l}\text { Vote share } \\
\text { of TMC }\end{array}$ & $\begin{array}{c}\text { Vote share } \\
\text { of TMC }\end{array}$ & $\begin{array}{c}\text { Vote share } \\
\text { of TMC }\end{array}$ & $\begin{array}{l}\text { Vote share } \\
\text { of CPIM }\end{array}$ & $\begin{array}{l}\text { Vote share } \\
\text { of CPIM }\end{array}$ & $\begin{array}{l}\text { Vote share } \\
\text { of CPIM }\end{array}$ \\
\hline \multirow[t]{2}{*}{ (Y_hat)*100000 } & $2.1 * * *$ & $2.2 * * *$ & $1.5 * * *$ & $-1.1 * * *$ & $-1.1 * * *$ & -0.92 \\
\hline & {$[3.28]$} & [3.98] & {$[2.92]$} & {$[-3.25]$} & {$[-3.17]$} & {$[-0.48]$} \\
\hline \multirow{2}{*}{$\begin{array}{l}\text { Percentage of Winning } \\
\text { Margin in } 2008 \\
\text { elections }\end{array}$} & & $0.65 * * *$ & $0.58 * * *$ & & $-0.07 * * *$ & -0.033 \\
\hline & & {$[6.86]$} & {$[5.68]$} & & {$[-2.52]$} & {$[-1.03]$} \\
\hline \multirow{2}{*}{$\begin{array}{l}\text { Percentage of vote of } \\
\text { other defeated } \\
\text { candidate in } 2008 \\
\text { elections }\end{array}$} & & 0.232 & 0.023 & & $-0.25 * * *$ & $-0.26 * * *$ \\
\hline & & {$[0.81]$} & {$[0.08]$} & & {$[-2.96]$} & {$[-2.93]$} \\
\hline \multirow{2}{*}{$\begin{array}{l}\text { Total Number of } \\
\text { Households }\end{array}$} & & -0.027 & $-0.022 *$ & & 0.002 & 0.001 \\
\hline & & {$[-1.89]$} & {$[-1.87]$} & & {$[0.19]$} & {$[0.22]$} \\
\hline \multirow{3}{*}{$\begin{array}{c}\text { Percentage BPL } \\
\text { Households in Village }\end{array}$} & & $0.48 * * *$ & $0.37 * * *$ & & 0.045 & 0.024 \\
\hline & & & & & & \\
\hline & & {$[3.67]$} & {$[3.62]$} & & {$[0.59]$} & {$[0.55]$} \\
\hline \multirow{3}{*}{$\begin{array}{l}\text { Percentage Minority } \\
\text { Households in Village }\end{array}$} & & $-0.32 *$ & -0.251 & & $-0.27 *$ & -0.106 \\
\hline & & & & & & \\
\hline & & {$[-1.69]$} & {$[-1.25]$} & & {$[-1.72]$} & {$[-1.23]$} \\
\hline \multirow{2}{*}{$\begin{array}{c}\text { Worker to Non-Worker } \\
\text { Ratio }\end{array}$} & & $-7.28^{*}$ & $-5.79^{*}$ & & $2.78^{*}$ & 3.108 \\
\hline & & {$[1.78]$} & {$[-1.91]$} & & [1.89] & {$[0.35]$} \\
\hline District Fixed Effects & & No & Yes & & No & Yes \\
\hline Observations & 329 & 329 & 329 & 673 & 673 & 673 \\
\hline$R^{2}$ & 0.0639 & 0.331 & 0.433 & 0.0374 & 0.0641 & 0.156 \\
\hline $\mathrm{F}$ & 10.75 & 24.45 & 12.221 & 10.59 & 8.88 & 5.76 \\
\hline
\end{tabular}

Note: Significance levels: * 10\%level, ** 5\% level, *** $1 \%$ level, t-ratios in brackets.

From Table 11 we see that TMC, as a ruling party after 2008 election at the GP level, has realised a 1.5 per cent increase in their vote share in their own villages in 2013 election by spending an extra INR 100000 NREGS funds annually in their own constituencies compared to opponent party constituency. However, the CPIM as the ruling party in the 2008 elections realised a fall in their vote share in their own constituencies in the 2013 elections, and once we control for district fixed effects, such a fall in the vote share becomes statistically insignificant. This means that fall in CPIM vote share in their ruling villages in 2013 cannot be attributed to the ruling party treatment effect. This is expected because for CPIM ruling villages we did not get any significant treatment effect earlier. 
In Table 12 we obtain similar results in the case where the dependent variable is a dummy variable which takes 1 if party gets re-elected and 0 otherwise. Here regression results show the marginal effect of the probit regression. Before presenting the regression results we refer to the Appendix 6, Table 6B, where we show re-election scenario by treatment and by party. From Appendix 6, Table 6B, we can infer that in 44.30 percent of the total constituencies, TMC candidates were re-elected in 2013 election whereas CPIM candidates were re-elected only in 26.15 percent of the total constituencies in 2013 election. However, when we look at the same re-election scenario within the treated villages, then we can see that TMC were reelected in 63.83 percent seats within the treated village whereas CPIM were re-elected in 22.10 percent seats within the treated villages. This indicates that partisan alignment certainly has some contribution in increasing the probability of getting re-elected.

Table 12: Marginal Effect on Ruling Party’s Probability of Getting Re-elected in 2013 Elections

\begin{tabular}{|c|c|c|c|c|}
\hline $\begin{array}{c}\text { Xs } \\
\text { (explanatory variables) }\end{array}$ & $\begin{array}{c}\mathrm{dY} / \mathrm{dX} \\
\text { (marginal effect on } \\
\text { probability of re- } \\
\text { election in } 2013 \text { in } \\
\text { TMC villages when } \\
\mathrm{T}=1 \text { ) }\end{array}$ & $\begin{array}{c}\text { X-bar } \\
\text { (Average value } \\
\text { of Xs in TMC } \\
\text { Villages when } \\
\quad \mathrm{T}==1 \text { ) }\end{array}$ & $\begin{array}{c}\mathrm{dY} / \mathrm{dX} \\
\text { (marginal effect on } \\
\text { probability of re- } \\
\text { election in } 2013 \text { in } \\
\text { CPIM villages when } \\
\mathrm{T}=1 \text { ) }\end{array}$ & $\begin{array}{c}\text { X-bar (Average } \\
\text { value of Xs in } \\
\text { CPIM villages } \\
\text { when } T=1 \text { ) }\end{array}$ \\
\hline \multirow[t]{2}{*}{ (Y_hat)*100000 } & $0.114^{* *}$ & $\begin{array}{c}(512345.33)^{*} \\
100000\end{array}$ & -.08001 & $\begin{array}{c}(411326.78)^{*} \\
100000\end{array}$ \\
\hline & [2.37] & - & {$[-0.71]$} & - \\
\hline \multirow[t]{2}{*}{$\begin{array}{l}\text { Percentage of Winning } \\
\text { Margin in } 2008 \\
\text { elections }\end{array}$} & $0.176^{* *}$ & 22.25 & -.00489 & 24.78 \\
\hline & {$[2.33]$} & - & {$[-1.55]$} & - \\
\hline \multirow[t]{2}{*}{$\begin{array}{l}\text { Percentage of vote of } \\
\text { other defeated } \\
\text { candidate in } 2008 \\
\text { elections }\end{array}$} & $-.165 * *$ & $\begin{array}{c}6.65 \\
-\end{array}$ & $-.0073^{*}$ & 6.33 \\
\hline & {$[-2.05]$} & & {$[-1.66]$} & - \\
\hline \multirow[t]{2}{*}{$\begin{array}{l}\text { Total Number of } \\
\text { Households }\end{array}$} & -.0003211 & 350.55 & $.000317^{*}$ & 375.132 \\
\hline & {$[-0.95]$} & - & {$[1.75]$} & - \\
\hline \multirow{2}{*}{$\begin{array}{c}\text { Percentage BPL } \\
\text { Households in Village }\end{array}$} & -.0005659 & 42.97 & -.0015378 & 40.09 \\
\hline & {$[-0.19]$} & - & {$[-1.06]$} & - \\
\hline \multirow{2}{*}{$\begin{array}{l}\text { Percentage Minority } \\
\text { Households in Village }\end{array}$} & .0008952 & 3.97 & .0015921 & 5.42 \\
\hline & {$[0.16]$} & - & {$[0.57]$} & - \\
\hline \multirow[t]{2}{*}{$\begin{array}{c}\text { Worker to Non-Worker } \\
\text { Ratio }\end{array}$} & .1992362 & 0.625 & -.3784496 & 0.666 \\
\hline & {$[0.24]$} & - & {$[-1.21]$} & - \\
\hline District Fixed Effects & Yes & & Yes & \\
\hline Observations & 329 & & 673 & \\
\hline Pseudo $R^{2}$ & 0.1657 & & 0.0705 & \\
\hline Prob $>$ Chi2 & 0.0018 & & 0.0000 & \\
\hline
\end{tabular}

Note: Significance levels: * $10 \%$ level, ** 5\% level, *** $1 \%$ level. t-ratios in brackets. 
In Table 12 we present marginal effects of preferential spending of NREGS funds in ruling party's villages on probability of getting re-elected. We can see that TMC realized a 11.4 percentage point increase in their probability of getting re-elected by spending extra INR 100000 NREGS fund in their own villages. However, the CPIM realized a 8 percentage point fall in the probability of getting re-elected but the result is statistically insignificant when district fixed effects are included.

To summarise our main findings, we find that there is partisan alignment in the allocation of NREGS funds. This practice is more pronounced when the TMC is the ruling party and we find TMC as ruling party spends around INR $125 \mathrm{~K}$ to $150 \mathrm{~K}$ more NREGS funds annually in their own villages compared to non-TMC villages. On the contrary, we did not find such a practice of partisan alignment when the CPIM is the ruling party. The CPIM as a ruling party spends less in their own party villages, but this result is statistically insignificant. We also find that due to the practice of partisan alignment, the TMC as a ruling party gained both in terms of the vote share and the higher probability of getting re-elected in 2013 panchayat election in their own party villages, while CPIM as a ruling party could not gain electorally in a similar manner.

\section{Why did the two incumbent parties behave differently in allocating NREGS funds?}

A striking result that we have obtained is the differences between the two main political parties in the manner they practised partisan alignment. We find that the CPIM as an incumbent ruling party did not spend more NREGS fund in their own party villages than opponent parties' villages, whereas TMC as an incumbent ruling party spent more NREGS fund in their own party villages compared to its opponent party villages. Why should there be differences between the two parties in practicing partisan alignment, especially given our finding that there was a clear positive electoral return to doing so? In this section, we provide possible explanations of the heterogeneous treatment effects that we observe across the two main political parties.

Firstly, it is possible to argue that the different behavior of the LF as compared to the TMC may be related to an impending change in the political regime that the LF could foresee. During a period of regime transition, it may be argued that the incumbent may behave differently compared to a normal time, especially when the incumbent can foresee that 
regime change (Peng, 2003; Vergne, 2006; Snyder and Mahoney, 1999; Kitschelt, 1992; Gandhi, 2014). Regime transitions have an important impact on the capacities and functioning of the incumbents who try to defend them and similarly regime institutions also influence the strategies of the challengers or entrants who seek to transform them. As we have noted in Section II, political parties expected a regime change since 2009, which eventually occurred in the 2011 state assembly elections. For the LF, there was no strong electoral reward anticipated in practicing partisan alignment during the period 2010-2012, once it was clear that they will lose control of the state government in 2011.

A second explanation may have to do with the class interests and core ideology of the LF, and the social base of their support in the years that they formed the local and state governments in West Bengal. The LF, and the CPIM in particular, is historically a political party based on middle and small peasantry class in West Bengal (Chakraborty, 2015). During its years in government, the CPIM's main focus was placed on land reform and tenancy reform whereby it protected the interest of the small and marginal farmers (ibid.), and secured their votes for regime survival (Bardhan and Mookherjee 2006, 2012) On the other hand, the NREGS is a programme which primarily targets agricultural labourers who are mostly landless and who have historically not been the support base of CPIM. Thus, the lack of partisan alignment practised by the LF when it came to the NREGS may be seen as being more in line with ideology based theories of political behavior, where incumbent parties do not directly use public programmes under their control for clientelist purposes, even when it is in their short-term electoral interests (Lipset 1960, Besley and Coate 1997)

\section{Conclusions}

Whether incumbent parties practise partisan alignment - that is, discriminate in favour of their own constituencies instead of the opponent party's constituencies - has been a matter of theoretical and empirical debate. The literature on partisan alignment also does not provide an unambiguous answer on whether incumbent parties gain electorally when they do practise partisan alignment. In this paper, we test for the presence of partisan alignment as well as the effect of such alignment on future election success of the incumbent party in the context of Village Council (i.e. Gram Panchayat) level ruling party in West Bengal Panchayats in distributing the NREGS funds using a quasi-experimental research design. We find that after the 2008 Panchayat elections, the ruling party at the GP level significantly spent more 
NREGS funds in the following years in their own party constituencies i.e. their own party villages compared to opponent party's villages. However, looking closely at the two major political parties in West Bengal - the TMC and CPIM, we find TMC practised partisan alignment strongly in their villages where they were the ruling party after 2008 election while the CPIM did not engage in a similar type of behaviour.

We also investigate the feedback effect of partisan alignment of the 2008 ruling parties on the election outcome after 2013 election. We find that this practice was rewarded in terms of the better election outcome in 2013 for the TMC. In contrast, the CPIM could not gain in terms of votes or likelihood of re-election in the following election due mainly to their nonclientelistic behaviour. We suggest that the differences in behaviour between the two political parties can be attributed to the anticipation of regime change in the state, which provided little incentive for the CPIM in engage in the practice of partisan alignment, as well as the class background of the potential beneficiaries of the NREGS, who have historically not been the core supporters of the Left regime in West Bengal. 


\section{References:}

Angrist, J. D., and Pischke, J.S. (2009): Mostly harmless econometrics: An empiricists companion. Princeton University Press. Princeton, New Jersey, USA.

Asher, Sam and Paul Novosad. (2015): Politics and Local Economic Growth: Evidence from India, mimeo.

Arulampalam, Wiji \& Dasgupta, Sugato \& Dhillon, Amrita \& Dutta, Bhaskar, 2009. Electoral goals and center-state transfers: A theoretical model and empirical evidence from India, Journal of Development Economics, Elsevier, vol. 88(1), pages 103-119, January

Banful, Afua Branoah, (2011a): Old Problems in the New Solutions? Politically Motivated Allocation of Programme Benefit and the "New" Fertilizer Subsidies, World Development, Elsevier, vol. 39(7), pages 1166-1176, July.

Banful, Afua Branoah, (2011b): Do formula-based intergovernmental transfer mechanisms eliminate politically motivated targeting? Evidence from Ghana, Journal of Development Economics, Elsevier, vol. 96(2), pages 380-390, November

Bardhan, Pranab and Mookherjee, Dilip (2006): Pro-poor targeting and accountability of local government in West Bengal, Journal of Development Economics, Vol. 79, Issue 2.

Bardhan, P., and Mookherjee, D.(2010a): Determinants of Redistributive Politics: An Empirical Analysis of Land Reform in West Bengal, India, American Economic Review, Volume 100, No. 4 1572-1600.

Bardhan, P., and Mookherjee, D.(2010b):Impact of Political Reservations in West Bengal Local Governments on Anti-Poverty Targeting, Journal of Globalisation and Development, Volume-1, Issue-1, Article-5

Bardhan, P., Mitra S., Mookherjee, D., Sarkar, A. (2009): Local Democracy and Clientelism: Implications for Political Stability in Rural West Bengal, Economic and Political Weekly, February 28, 2009 vol. xliv no. 9,

Bardhan, Pranab and Mookherjee, Dilip (2012): Political Clientelism and Capture: Theory and Evidence from West Bengal, India, UNU-WIDER, Working Paper No. 2012/97,

Barua, Sanjib (1990): The End of the Road in Land Reform? Limits to Redistribution in West Bengal, Development and Change, Vol. 21, pp. 119-146

Benhabib, J and Przeworski, Adam (2006): The Political Economy of redistribution under democracy, Economic Theory, Volume 29, Issue 2, pp 271-290

Besley, T. and S. Coate (1992): Workfare versus Welfare: Incentive Arguments for Work Requirements in Poverty-Alleviation Programs, American Economic Review, Vol. 82, No. 1, pp. 249-261.

Besley, Timothy \&Coate, Stephen, 1997. "An Economic Model of Representative Democracy," The Quarterly Journal of Economics, MIT Press, vol. 112(1), pages 85-114, 
Bhattacharia, Dwaipayan (2009): Of Control and Factions: The Changing 'Party-Society' in Rural West Bengal, Economic and Political Weekly, Vol. XLIV, No. 9

Bhattacharia, Debraj (2012): Panchayati Raj in West Bengal: A Synthesis of Existing Research, Scribd book, available at https://www.scribd.com/doc/108819168/West-Bengal-Panchayats-AReview-of-literature.

Brollo, F., Nannicini, T., Perotti, R., Tabellini, G. (2010): The Political Resources Curse, NBER Working Paper Series, Working Paper 15705.

Case, A., 2001. Election goals and income redistribution: recent evidence from Albania. European Economic Review 45, 405-423.

Caselli, F. And Michaels, G. (2009): Do Oil Windfalls Improve Living Standards? Evidence from Brazil, NBER Working Paper No. 15550.

Cerda, Rodrigo, and Rodrigo Vergara (2008): Government Subsidies and Presidential Election Outcome: Evidence from a Developing Country. World Development 36(11): 2470-88.

Chakraborty, Bidyut (2015): Left Radicalism in India, Routledge Contemporary South Asia Series, Routledge.

Chatterjee, Partha (2009): The Coming Crisis in West Bengal, Economic and Political Weekly, Vol. XLIV, No. 9

Chopra, Deepta (2014): 'They don't want to work versus 'they don't want to provide work': Seeking explanations for the decline of MGNREGA in Rajasthan, ESID Working paper no. 31, Effective State and Inclusive Development, University of Manchester.

Cox, Garry W (2010): swing Voters, Core Voters, and Distributive Politics. In Political Representation, ed. Ian Shapiro, Susan C. Stokes, Elisabeth Jean Wood and Alexander S. Kirshner. Cambridge: Cambridge University Press, 342-57.

Cox, G., \&McCubbins, M. (1986): Electoral Politics as a redistributive game, Journal of Politics, 48, 370-389.

CPIM Panchayat Election Manifesto 2003, 2008, 2013: Communist Party of India (Marxist), West Bengal Stata Committee

Crook, Richard C. and Sverrisson, Alan Sturla (2001): Decentralisation and poverty-alleviation in developing countries: a comparative analysis or, is West Bengal unique? IDS Working Paper 130, Institute of Development Studies, University of Sussex.

Dahlberg, M., Johansson, E., 2002. On the vote-purchasing behaviour of incumbent governments. American Political Science Review 96, 27-47.

Dasgupta, Rajarshi (2009): The CPI(M) 'Machinery' in West Bengal: Two Village Narratives from Kochbihar and Malda, Economic \& Political Weekly, 2009 vol. xliv no 9

Dasgupta, S., Dhillon, A., Dutta, B., 2004. Electoral Goals and Centre-State Transfers in India. University of Warwick Working Paper 
De La O, Ana L (2013): Do Conditional Cash Transfer Affect Electoral Behaviour? Evidence from a Randomised Experiment in Mexico. American Journal of Political Science, Vol. 57, No. 1, PP 1-14.

D'1az-Cayeros, Alberto, Federico Est'evez, and Beatriz Magaloni.(2007): "Strategies of Vote Buying: Social Transfers, Democracy and Welfare in Mexico." Unpublished manuscript. Stanford University.

D'1az-Cayeros, Alberto, Federico Est'evez, and Beatriz Magaloni. (2009): "Welfare Benefits, Canvassing and Campaign Handouts." In Consolidating Mexico's Democracy: The 2006 Presidential Campaign in Comparative Perspective, ed. Jorge Dom'inguez, Chappell Lawson, and Alejandro Moreno. Baltimore: Johns Hopkins University Press, 229-331.

Dixit, Avinash(1996): The Determinants of Success of Special Interests in Redistribution Politics, Journal of Politics, Vol. 58, No. 4, 1132-55

Dixit, A., and Londregan, J. (1996): "The Determinants of Success of Special Interests in Redistributive Politics,” Journal of Politics, Volume 58, Issue 4, PP 1132-1155

Dunning, T., \& Stokes, S. (2009): Clientelism as persuasion and as mobilisation, Unpublished manuscript

Finan, Frederico and Schechter, Laura A. (2012): Vote Buying and Reciprocity, Econometrica, Vol. 80, No. 2 (March, 2012), 863-881

Fried. J. Brian (2011): Distributive Politics and Conditional Cash Transfer: The Case of Brazil's BolsaFamilia, World Development, Vol. 40, No. 5, pp. 1042-1053

Gandhi, Jenifar (2014): Authoritarian Elections and Regime Change, Chapter-10, Comparing 4 Democracies: Election and Voting in Changing World, edited by Lawrence LeDuc, Richard G. Niemi and Pippa Norris, Sage Publication.

Gervasoni, C. (2010): A Rentier Theory of Subnational Regimes: Fiscal Federalism, Democracy, and Authoritarianism in the Argentine Provinces, World Politics 62(2): 302-40.

Goldberg, E.,E. Wibbels, and E. Mvukiyehe (2008): Lessons from Strange Cases: Democracy, Development, and the Resource Curse in the U.S. States. Comparative Political Studies 41(4-5): 477-514

Gonzalez-Ocantos, Ezequiel, Chad Kiewiet de Jonge, Carlos Melendez, Javier Osorio, and David Nickerson (2012): Vote Buying and Social Desirability Bias: Experimental Evidence from Nicaragua. American Journal of Political Science 56(1): 202-17

Imbens, G. W., andAngrist, J. D.(1994)Identification and estimation of local average treatment effect, Econometrica, vol. 142 no. 2, pp 615-635

Imbens, Guido W. and Lemieux, Thomas (2008): Regression discontinuity designs: A guide to practice, Journal of Econometrics, vol. 142, pp 615-635 
Johansson, E., 2003. Intergovernmental grants as a tactical instrument: empirical evidence from Swedish municipalities. Journal of Public Economics 87, 883-915.

Kartik, N. and P. McAfee (2007), Signalling Character in Electoral Competition, American Economic Review, 97(3):852-869.

Kitschelt, Herbert (1992): Political Regime Change: Structure and Process Driven Explanation? American Political Science Review, Vol.86/issue 4/ PP 1028-1034.

Labonne, Julien (2013): The local electoral impacts of conditional cash transfers Evidence from a field experiment. Journal of Development Economics, 104 (2013) 73-88.

Lee, D.S. and Card, D. (2008): 'Regression discontinuity inference with specification error', Journal of Econometrics, Volume.142, no. 2, pp. 655-74

Lee, David S. and Lemieux, Thomas(2009): Regression Discontinuity Design in Economics, NBER Working paper series, working paper no. 14723

Levitt, Steven D., and James M. Snyder Jr. (1997): The impact of Federal Spending on House Election Outcome. Journal of Political Economy 105 (1): 30-53

Lindbeck, A., \& Weibull, J.W. (1987): Balanced-budget redistribution as the outcome of political competition. Public Choice, 52(3), 273-297.

Lipset, Seymour M., (1960): Political Man, Baltimore: John Hopkins University.

Litschig, Stephan, Morrison, Kevin (2010): Government Spending and Re-election: Quasi Experimental Evidence from Brazilian Municipalities, mimeo.

Litschig, Stephan and Morrison, Kevin (2012): Government Spending and Re-election: QuasiExperimental Evidence from Brazilian Municipalities, Barcelona Graduate School of Economics, Working paper no. 515.

Mallik, Md. Ayub ( 2013): Kohli-Williams Debate And The Decline of The Left In West Bengal, International Journal of Innovative Research and Development, August, 2013, Vol 2 Issue 8

Manacorda, Marco, Edward Miguel, and Andrea Vigorito.(2011). "Government Transfers and Political Support." American Economic Journal: Applied Economics, 3(3): 1-28.

McCary, Justin (2008): Manipulation of the running variable in the regression discontinuity design: A density test, Journal of Econometrics, Volume 142, pp 698-714.

Muralidharan, K., P. Niehaus and S. Sukhtankar (2015), Building State Capacity: Evidence from Biometric Smartcards in India, mimeo

Nazareno, Marcelo, Susan Stokes and Valeria Brusco (2006): Revenues and electoral hazards of public spending in Argentina. Desarrollo Economico (Economic Development): 46(181): 63-88.

Nichter, Simeon (2008): Vote Buying or Turnout Buying? Machine Politics and the Secret Ballot, American Political Science Review, Volume 102/ Issue 01/ February 2008/ pp 19-31. 
Niehas, P. and S. Sukhtanker (2013): The marginal rate of corruption in public programs:

Evidence from India, Journal of Public Economics, Vol. 104, pp. 52-64

Peng W. Mike (2003): Institutional Transition and Strategic Choices, Academy of Management Review, Vol. 28, No. 2, pp 275-296.

Person, T. And Tabellini, G. (2000): Political Economics: Explaining Economic Policy, MIT

Pierson, Paul (1996): The New Politics of Welfare State. World Politics 48(2): 143-79

Rana, Kumar (2013): 2013 Panchayat Election in West Bengal- A Role Reversal? Economic and Political Weekly, Vol. XLVIII No. 30

Ravallion, M., Dutta, P., Murgai, R., Walle, D. van de. (2012): Does India's Employment Guarantee Scheme Guarantee Employment? Policy Research Working Paper 6003, World Bank.

Robinson, James A., and Verdier, Thierry. (2013): The Political Economy of Clientelism, The Scandinavian Journal of Economics, 115(2), 260-291, 2013

Synder, Richard and Mohaney, James (1999): Review: The Missing Variable: Institutions and the Study of Regime Change, Comparative Politics, Vol. 32, No. 1 (Oct., 1999), pp. 103-122.

Solé-Ollé, Albert and Sorribas-Navarro, Pilar, (2008). The effects of partisan alignment on the allocation of intergovernmental transfers. Differences-in-differences estimates for Spain, Journal of Public Economics, Elsevier, vol. 92(12), pages 2302-2319, December.

Strömberg, D., (2002). Optimal campaigning in presidential elections: the probability of being Florida. Seminar Paper 706, Institute for International Economic Studies, Stockholm University

Vergne, Clemence (2006): Democracy, Election and Allocation of Public Expenditure in Developing Countries. HAL Id: halshs-00564572, https://halshs.archives-ouvertes.fr/halshs00564572

Webster, Neil (1992): Panchayati Raj in West Bengal: Popular Participation for the People of the Party?, Development and Change, Vol. 23, no. 4, pp. 129-163

Werker, E., Cole, S., Healy, A. (2012): Do Voters demand responsive governments? Evidence from Indian disaster relief, Journal of Development Economics, Vol. 97, 167-181.

Williams, Glyn (2001): Understanding 'Political Stability': Party Action and Political Discourses in West Bengal, Third World Quarterly, Vol. 22, No. 4, pp 603-622

Zucco, Cesar. (2011): "Conditional Cash Transfers and Voting Behavior: Redistribution and Clientelism in Developing Countries.” Unpublished manuscript. Princeton University. 


\section{Appendix 1: Summary statistics of village level variable by ruling party village (When CPIM is the Ruling Party)}

\begin{tabular}{|l|l|l|l|}
\hline $\begin{array}{l}\text { Variable } \\
\text { (all values refer the average value at village } \\
\text { level) }\end{array}$ & $\begin{array}{l}\text { Values in } \\
\text { Ruling party } \\
\text { Village } \\
\text { K=1) }\end{array}$ & $\begin{array}{l}\text { Values in Not- } \\
\text { ruling party } \\
\text { Village (K=0) }\end{array}$ & $\begin{array}{l}\text { t-test for } \\
\text { mean } \\
\text { difference }\end{array}$ \\
\hline NREGS Expenditure (Y) & 330148.4 & 302944.9 & 0.6495 \\
\hline NREGS days generated annually & 2749.887 & 2365.5 & 1.0731 \\
\hline NREGS days worked by Per NREGS HH (Y7) & 24.8656 & 25.657 & 0.2344 \\
\hline NREGS days worked by Per HH (y) & 8.74 & 7.504 & 1.0729 \\
\hline NREGS Wage & 121.624 & 123.395 & 1.0721 \\
\hline Total Schemes completed in a year (Y5) & 2.788 & 2.7266 & 0.2065 \\
\hline Average expenditure per schemes (Y6) & 126268.1 & 121001.5 & 0.4441 \\
\hline No. of new schemes completed (Y1) & 2.2448 & 2.214815 & 0.1132 \\
\hline No. of existing schemes completed (Y2) & 0.735 & 0.661 & 0.4983 \\
\hline No. of total Job Car (Y3) & 251.879 & 247.97 & 0.2582 \\
\hline No. of active Job card (Y4) & 138.40 & 92.87 & $3.2771 * * *$ \\
\hline GP level ruling party vote share at GS (X1) & 58.5022 & 39.48648 & $12.915^{* * *}$ \\
\hline Total Voters in 2008 Election & 974.9 & 983.187 & 0.2948 \\
\hline Percentage of voters casted their vote in 2008 & 87.484 & 90.326 & $3.5651^{* * *}$ \\
\hline Total monsoon rain annually (in millimetre) & 1414.14 & 1242.549 & $3.6178^{* * *}$ \\
\hline No. of households (as per RHS) & 375.132 & 397.23 & 1.1490 \\
\hline No. of BPL households (as per RHS) & 152.352 & 155.53 & 0.2343 \\
\hline No. of minority households (as per RHS) & 20.2 & 58.93 & $5.3631^{* * *}$ \\
\hline Worker to Non-worker ratio & 0.66698 & 0.5826725 & $5.9496^{* * *}$ \\
\hline Percentage of male village-member 2008 & 62.4 & 61.15 & 0.2425 \\
\hline Percentage of female village-member 2008 & 37.6 & 38.85 & 0.2425 \\
\hline $\begin{array}{l}\text { Percentage of General caste village-member } \\
\text { 2008 }\end{array}$ & 34.4 & 34.53 & 0.0263 \\
\hline Percentage of SC village-member 2008 & 42.4 & 39.57 & 0.5422 \\
\hline Percentage of ST village-member 2008 & 12.8 & 2.16 & $3.5630^{* * *}$ \\
\hline Percentage of OBC village-member 2008 & 4 & 6.47 & 1.0841 \\
\hline $\begin{array}{l}\text { Percentage of Minority caste village-member } \\
\text { 2008 }\end{array}$ & 6.4 & 17.26 & $3.4233^{* * *}$ \\
\hline Number of observation & 250 & 139 & \\
\hline
\end{tabular}




\section{Appendix 2: Summary statistics of village level variables by ruling party village}

(When TMC is the ruling party)

\begin{tabular}{|l|l|l|l|}
\hline $\begin{array}{l}\text { Variable } \\
\text { (all values refer the average value at GS level) }\end{array}$ & $\begin{array}{l}\text { Values in } \\
\text { Ruling party } \\
\text { Village } \\
\text { (L=1) }\end{array}$ & $\begin{array}{l}\text { Values in } \\
\text { Not-ruling } \\
\text { party Village } \\
\text { (L=0) }\end{array}$ & $\begin{array}{l}\text { t-stats from } \\
\text { t-test for } \\
\text { mean } \\
\text { difference. }\end{array}$ \\
\hline NREGS Expenditure (Y) & 595593.7 & 499220.7 & 0.8414 \\
\hline NREGS days generated annually & 4803.382 & 3967.204 & 0.9406 \\
\hline NREGS days worked by Per NREGS HH (Y7) & 50.75019 & 54.777 & 0.3451 \\
\hline NREGS days worked by Per HH (y) & 15.33158 & 17.0314 & 0.4039 \\
\hline NREGS Wage & 120.6 & 122.56 & 0.7327 \\
\hline Total Schemes completed in a year (Y5) & 2.964912 & 3.2553 & 0.6190 \\
\hline Average expenditure per schemes (Y6) & 167777.4 & 114349.4 & $2.0401^{* * *}$ \\
\hline No. of new schemes completed (Y1) & 2.508772 & 2.5106 & 0.0039 \\
\hline No. of existing schemes completed (Y2) & 0.5098039 & 0.9210 & $2.5645 * * *$ \\
\hline No. of total Job Car (Y3) & 246.6833 & 256.06 & 0.4927 \\
\hline No. of active Job card (Y4) & 124.3898 & 109.48 & 0.9770 \\
\hline GP level ruling party vote share at GS (X2) & 57.80032 & 27.83477 & $14.0582 * * *$ \\
\hline Total Voters in 2008 Election & 1073.217 & 1083.74 & 0.2065 \\
\hline Percentage of voters casted their vote in 2008 & 85.25379 & 87.2757 & 09467 \\
\hline Total monsoon rain annually (in millimetre) & 1301.06 & 1255.124 & 1.3164 \\
\hline No. of households (as per RHS) & 350.5583 & 420.64 & $2.4049 * *$ \\
\hline No. of BPL households (as per RHS) & 151.7333 & 146.3 & 0.3229 \\
\hline No. of minority households (as per RHS) & 12.575 & 32.42 & $2.9931^{* *}$ \\
\hline Worker to Non-worker ratio & 0.6251478 & 0.6245263 & 0.0421 \\
\hline Percentage of male village-member 2008 & 58.33 & 56 & 0.2790 \\
\hline Percentage of female village-member 2008 & 41.67 & 44 & 0.2790 \\
\hline $\begin{array}{l}\text { Percentage of General caste village-member } \\
\text { 2008 }\end{array}$ & 20.84 & 44 & $3.1480^{* * *}$ \\
\hline Percentage of SC village-member 2008 & 60.83 & 48 & 1.5420 \\
\hline Percentage of ST village-member 2008 & 6.66 & 2 & 1.2364 \\
\hline Percentage of OBC village-member 2008 & 5 & 0 & 1.6126 \\
\hline $\begin{array}{l}\text { Percentage of Minority caste village-member } \\
\text { 2008 }\end{array}$ & 6.67 & 6 & 0.1601 \\
\hline Number of observation & 120 & 50 & \\
\hline & & & \\
\hline
\end{tabular}




\section{Appendix 3: Cross Validation Procedure.}

The optimal bandwidth is chosen with a 'leave one out' procedure proposed by Imbens and Lemieus (2008). For each observation ' $i$ ' on the left of the cut-off point, we run a linear regression using only observation with value of $X$ (i.e. the treatment determining assignment variable) on the left of $X_{i}\left(X_{i}-h \leq X<X_{i}\right)$, while for observation on the right of the cut-off point we use only those on the right of $X_{i}\left(X_{i}-h \leq X<X_{i}\right)$. Then we repeat this procedure for each ' $i$ ' in order to obtain the whole set of predicted value of $Y$ that can be compared with the actual value of Y. In terms of formal expression, the cross-validation criterion is defined as the following expression

$$
C V_{Y}(h)=\frac{1}{N} \sum_{i=1}^{N_{h}}\left\{Y_{(i)}-\hat{Y}\left[X_{(i)}\right]\right\}^{2}
$$

where $\hat{Y}\left[X_{(i)}\right]$ represents the predicted value of $\mathrm{Y}$ using the above described regression. The optimal bandwidth is that value of $h$ that minimises the criterion function. In our case this optimal bandwidth is 5 in local linear regression. Following Imbens and Lemieus (2008) suggestion we used same bandwidth for both outcome and treatment equation and use the smallest bandwidth which is 5 selected by the cross validation procedure.

\section{Appendix 4: Akaike Information Criterion.}

Our second estimation procedure is based on polynomial regression. Under this polynomial regression main problem is to choose the optimal order of polynomial of the assignment variable to capture the true functional form of the $f(x)$ in Equation 2. Here we use Akaike information criterion (AIC) as defined below

$$
A I C=N \ln (\hat{\eta})^{2}+2 p,
$$

Where $\hat{\eta}$ is the mean square error of the regression and $p$ is the number of the parameters in the model. Based on AIC criterion we use quartic form $x$ i.e. polynomial of order 4 as the optimal order. 
Appendix 5

Table 5A: Treatment Effect on Village Wise NREGS Expenditure: With whole sample (Local Linear Regression with all Covariates at different band width)

\begin{tabular}{|c|c|c|c|c|c|c|}
\hline & $\mathrm{h}=10$ & $\mathrm{~h}=9$ & $\mathrm{~h}=8$ & $\mathrm{~h}=7$ & $\mathrm{~h}=6$ & $\mathrm{~h}=5$ \\
\hline T(Treatment Effect) & $\begin{array}{c}30451.9 * * \\
{[2.23]}\end{array}$ & $\begin{array}{c}34201.9^{* *} \\
{[2.38]}\end{array}$ & $\begin{array}{c}27227.8^{*} \\
{[1.82]}\end{array}$ & $\begin{array}{c}31361.7^{*} \\
{[1.80]}\end{array}$ & $\begin{array}{c}36008.3^{*} \\
{[1.94]}\end{array}$ & $\begin{array}{c}40698.2 * * \\
{[2.00]}\end{array}$ \\
\hline $\mathrm{x}$ (Assignment var.) & $\begin{array}{c}-2122.2^{* *} \\
{[-2.19]}\end{array}$ & $\begin{array}{c}-2269.5^{* *} \\
{[-2.19]}\end{array}$ & $\begin{array}{c}-2616.8^{* * *} \\
{[-2.27]}\end{array}$ & $\begin{array}{c}-3156.1 * * \\
{[-2.11]}\end{array}$ & $\begin{array}{c}-3516.4 * * \\
{[-2.11]}\end{array}$ & $\begin{array}{c}-4583.3 * * \\
{[-2.39]}\end{array}$ \\
\hline$Z^{*} \mathrm{x}$ (interaction) & $\begin{array}{c}2000.174 \\
{[1.46]}\end{array}$ & $\begin{array}{c}1889.584 \\
{[1.30]}\end{array}$ & $\begin{array}{c}2777.16^{*} \\
{[1.68]}\end{array}$ & $\begin{array}{c}3330.78^{*} \\
{[1.77]}\end{array}$ & $\begin{array}{c}3272.37 \\
{[1.61]}\end{array}$ & $\begin{array}{c}3672.02^{*} \\
{[1.73]}\end{array}$ \\
\hline Total_voters_2008 & $\begin{array}{c}24.6 * * * \\
{[2.91]}\end{array}$ & $\begin{array}{c}25.5^{* * * *} \\
{[3.00]}\end{array}$ & $\begin{array}{c}27.4 * * * \\
{[3.25]}\end{array}$ & $\begin{array}{c}30.06 * * * \\
{[3.39]}\end{array}$ & $\begin{array}{c}25.3 * * * \\
{[2.87]}\end{array}$ & $\begin{array}{c}23.4 * * * \\
{[2.73]}\end{array}$ \\
\hline$\%$ \%_vote casted_2008 & $\begin{array}{c}-14.312 \\
{[-0.06]}\end{array}$ & $\begin{array}{c}-18.902 \\
{[-0.08]}\end{array}$ & $\begin{array}{c}104.571 \\
{[0.44]}\end{array}$ & $\begin{array}{l}78.792 \\
{[0.30]}\end{array}$ & $\begin{array}{c}139.508 \\
{[0.52]}\end{array}$ & $\begin{array}{c}-218.936 \\
{[-0.87]}\end{array}$ \\
\hline \%_margin_win 2008 & $\begin{array}{c}-328.021 \\
{[-0.89]}\end{array}$ & $\begin{array}{c}-343.316 \\
{[-0.92]}\end{array}$ & $\begin{array}{c}-257.602 \\
{[-0.66]}\end{array}$ & $\begin{array}{c}-264.862 \\
{[-0.50]}\end{array}$ & $\begin{array}{c}-232.248 \\
{[-0.43]}\end{array}$ & $\begin{array}{c}184.404 \\
{[0.29]}\end{array}$ \\
\hline$\%$ _vote_others_defeatedcandidate 2008 & $\begin{array}{c}-899.02 * * \\
{[-2.17]}\end{array}$ & $\begin{array}{c}-904.27 * * \\
{[-2.14]}\end{array}$ & $\begin{array}{c}-1132.11^{* *} \\
{[-2.51]}\end{array}$ & $\begin{array}{c}-1258.44^{* *} \\
{[-2.02]}\end{array}$ & $\begin{array}{c}-1170.36^{*} \\
{[-1.86]}\end{array}$ & $\begin{array}{c}-1708.36^{* *} \\
{[-2.26]}\end{array}$ \\
\hline Monsoon rain & $\begin{array}{c}-40.5 * * * \\
{[-3.16]}\end{array}$ & $\begin{array}{c}-46.6 * * * \\
{[-3.63]}\end{array}$ & $\begin{array}{c}-50.8 * * * \\
{[-3.80]}\end{array}$ & $\begin{array}{c}-52.8 * * * \\
{[-3.86]}\end{array}$ & $\begin{array}{c}-43.7 * * * \\
{[-3.13]}\end{array}$ & $\begin{array}{c}-44.5 * * * \\
{[-3.03]}\end{array}$ \\
\hline Average $\mathrm{HH}$ size & $\begin{array}{l}5.169 \\
{[0.42]}\end{array}$ & $\begin{array}{l}-6.654 \\
{[-0.57]}\end{array}$ & $\begin{array}{l}-5.261 \\
{[-0.44]}\end{array}$ & $\begin{array}{l}-4.608 \\
{[-0.37]}\end{array}$ & $\begin{array}{l}-5.531 \\
{[-0.43]}\end{array}$ & $\begin{array}{l}2.193 \\
{[0.17]}\end{array}$ \\
\hline pct_BPLhh & $\begin{array}{c}378.9 * * * \\
{[4.86]}\end{array}$ & $\begin{array}{c}390.0 * * * \\
{[4.78]}\end{array}$ & $\begin{array}{c}415.8 * * * \\
{[5.09]}\end{array}$ & $\begin{array}{c}420.3 * * * \\
{[4.92]}\end{array}$ & $\begin{array}{c}391.1 * * * \\
{[4.52]}\end{array}$ & $\begin{array}{c}421.9 * * * \\
{[4.74]}\end{array}$ \\
\hline pct_Minority_hh & $\begin{array}{c}-61.818 \\
{[-0.63]}\end{array}$ & $\begin{array}{c}-65.403 \\
{[-0.67]}\end{array}$ & $\begin{array}{c}-55.990 \\
{[-0.57]}\end{array}$ & $\begin{array}{l}-23.078 \\
{[-0.21]}\end{array}$ & $\begin{array}{c}-24.738 \\
{[-0.22]}\end{array}$ & $\begin{array}{r}-28.393 \\
{[-0.25]}\end{array}$ \\
\hline Worker to Non-Worker Ratio & $\begin{array}{c}163637.8^{* * *} \\
{[4.77]}\end{array}$ & $\begin{array}{c}150541.2^{* * *} \\
{[4.29]}\end{array}$ & $\begin{array}{c}183791.5^{* * * *} \\
{[5.06]}\end{array}$ & $\begin{array}{c}190298.8^{* * *} \\
{[4.79]}\end{array}$ & $\begin{array}{c}196755.3^{* * *} \\
{[4.84]}\end{array}$ & $\begin{array}{c}212840.8^{* * *} \\
{[5.14]}\end{array}$ \\
\hline sex_member_2008== Male & $\begin{array}{c}1062.033 \\
{[0.26]}\end{array}$ & $\begin{array}{c}3306.529 \\
{[0.82]}\end{array}$ & $\begin{array}{c}5263.393 \\
{[1.28]}\end{array}$ & $\begin{array}{c}5855.626 \\
{[1.33]}\end{array}$ & $\begin{array}{c}6852.083 \\
{[1.54]}\end{array}$ & $\begin{array}{c}4389.197 \\
{[0.97]}\end{array}$ \\
\hline caste_member_2008= $=\mathrm{SC}$ & $\begin{array}{c}-8201.63 * \\
{[-1.73]}\end{array}$ & $\begin{array}{c}-7838.989 \\
{[-1.64]}\end{array}$ & $\begin{array}{c}-5599.000 \\
{[-1.20]}\end{array}$ & $\begin{array}{c}-6592.914 \\
{[-1.31]}\end{array}$ & $\begin{array}{c}-6352.226 \\
{[-1.24]}\end{array}$ & $\begin{array}{c}-5938.386 \\
{[-1.15]}\end{array}$ \\
\hline caste_member_2008 $==\mathrm{ST}$ & $\begin{array}{c}16634.42 * \\
{[1.67]}\end{array}$ & $\begin{array}{c}14943.420 \\
{[1.46]}\end{array}$ & $\begin{array}{c}20959.5 * * \\
{[1.98]}\end{array}$ & $\begin{array}{c}20596.32^{*} \\
{[1.70]}\end{array}$ & $\begin{array}{c}23019.47 * \\
{[1.71]}\end{array}$ & $\begin{array}{c}27124.37^{*} \\
{[1.91]}\end{array}$ \\
\hline caste_member_2008 $==\mathrm{OBC}$ & $\begin{array}{c}11225.206 \\
{[1.12]}\end{array}$ & $\begin{array}{c}10562.695 \\
{[1.06]}\end{array}$ & $\begin{array}{c}13722.923 \\
{[1.25]}\end{array}$ & $\begin{array}{c}16281.933 \\
{[1.42]}\end{array}$ & $\begin{array}{c}17281.309 \\
{[1.47]}\end{array}$ & $\begin{array}{c}23675.96^{*} \\
{[1.84]}\end{array}$ \\
\hline caste_member_2008==Muslim & $\begin{array}{c}-18748.0 * * \\
{[-2.62]}\end{array}$ & $\begin{array}{c}-18973.6 * * \\
{[-2.66]}\end{array}$ & $\begin{array}{c}-22803.2 * * * \\
{[-3.23]}\end{array}$ & $\begin{array}{c}-24162.3 * * * \\
{[-3.29]}\end{array}$ & $\begin{array}{c}-23252.8^{* * *} \\
{[-3.07]}\end{array}$ & $\begin{array}{c}-25927.2 * * * \\
{[-3.29]}\end{array}$ \\
\hline year $==2011$ & $\begin{array}{c}13155.1^{* *} \\
{[2.28]}\end{array}$ & $\begin{array}{c}12665.7^{* *} \\
{[2.12]}\end{array}$ & $\begin{array}{c}11585.1^{*} \\
{[1.92]}\end{array}$ & $\begin{array}{c}10950.8^{*} \\
{[1.73]}\end{array}$ & $\begin{array}{c}14262.1^{* *} \\
{[2.28]}\end{array}$ & $\begin{array}{c}14678.5^{* *} \\
{[2.28]}\end{array}$ \\
\hline year $==2012$ & $\begin{array}{c}-6983.160 \\
{[-1.28]}\end{array}$ & $\begin{array}{c}-6179.342 \\
{[-1.14]}\end{array}$ & $\begin{array}{c}-6912.327 \\
{[-1.25]}\end{array}$ & $\begin{array}{c}-7262.633 \\
{[-1.30]}\end{array}$ & $\begin{array}{c}-1424.847 \\
{[-0.26]}\end{array}$ & $\begin{array}{c}-1441.184 \\
{[-0.26]}\end{array}$ \\
\hline district $==$ Purulia & $\begin{array}{c}-101856.5^{* * *} \\
{[-3.95]}\end{array}$ & $\begin{array}{c}-118305 * * * \\
{[-4.69]}\end{array}$ & $\begin{array}{c}-131594 * * * \\
{[-4.94]}\end{array}$ & $\begin{array}{c}-136746.1 * * * \\
{[-5.02]}\end{array}$ & $\begin{array}{c}-113964.7^{* * *} \\
{[-4.02]}\end{array}$ & $\begin{array}{c}-113526.7^{* * *} \\
{[-3.75]}\end{array}$ \\
\hline district $==$ South 24 Parganas & $\begin{array}{c}-55679.8 * * \\
{[-2.58]}\end{array}$ & $\begin{array}{c}-67492.1 * * * \\
{[-3.18]}\end{array}$ & $\begin{array}{c}-72369.3 * * * \\
{[-3.28]}\end{array}$ & $\begin{array}{c}-72542.5^{* * *} \\
{[-3.13]}\end{array}$ & $\begin{array}{c}-52208.6^{* *} \\
{[-2.12]}\end{array}$ & $\begin{array}{c}-43279.0^{*} \\
{[-1.65]}\end{array}$ \\
\hline Observations & 573 & 553 & 517 & 490 & 474 & 457 \\
\hline$R^{2}$ & 0.252 & 0.253 & 0.316 & 0.310 & 0.279 & 0.290 \\
\hline $\mathrm{F}$ & 8.470 & 8.769 & 9.096 & 8.877 & 8.003 & 7.517 \\
\hline
\end{tabular}

$t$ statistics in brackets; ${ }^{*} \mathrm{p}<0.10, * * \mathrm{p}<0.05, * * * \mathrm{p}<0.01$ 
Table 5B: Treatment Effect on Village Wise NREGS days per NREGS household: With whole sample (Local Linear Regression with all Covariates at different band width)

\begin{tabular}{|c|c|c|c|c|c|c|}
\hline & $\mathrm{h}=10$ & $\mathrm{~h}=9$ & $\mathrm{~h}=8$ & $\mathrm{~h}=7$ & $\mathrm{~h}=6$ & $\mathrm{~h}=5$ \\
\hline \multirow[t]{2}{*}{ T(Treatment Effect) } & $3.5 * * *$ & $3.8 * * *$ & $4.2 * * *$ & $4.2 * * *$ & $4.3 * * *$ & $4.8 * * *$ \\
\hline & {$[2.92]$} & {$[3.11]$} & {$[2.98]$} & {$[2.71]$} & {$[2.63]$} & {$[2.66]$} \\
\hline \multirow[t]{2}{*}{ x(Assignment Var.) } & $-1.9 * * *$ & $-2.0 * *$ & $-3.0 * * *$ & $-2.9 * *$ & $-3.3 * *$ & $-4.3 * *$ \\
\hline & {$[-2.66]$} & {$[-2.54]$} & {$[-2.71]$} & {$[-2.30]$} & {$[-2.27]$} & {$[-2.55]$} \\
\hline \multirow{2}{*}{$Z^{*} \mathrm{x}$ (interaction) } & 1.216 & 1.148 & 1.936 & 1.206 & 2.050 & 2.153 \\
\hline & {$[1.17]$} & {$[1.04]$} & [1.29] & {$[0.80]$} & {$[1.17]$} & [1.19] \\
\hline \multirow[t]{2}{*}{ Total_voters_2008 } & $0.02 *$ & $0.02 *$ & $0.02 * *$ & $0.03 * *$ & $0.03 * *$ & $0.03 *$ \\
\hline & [1.91] & {$[1.93]$} & {$[2.04]$} & {$[2.12]$} & {$[2.15]$} & {$[1.96]$} \\
\hline \multirow[t]{2}{*}{$\%$ \% vote casted_2008 } & -0.023 & -0.033 & 0.142 & 0.127 & 0.144 & -0.212 \\
\hline & {$[-0.11]$} & {$[-0.15]$} & {$[0.59]$} & {$[0.48]$} & {$[0.54]$} & {$[-0.87]$} \\
\hline \multirow[t]{2}{*}{$\%$ \%margin_win 2008} & 0.037 & 0.034 & 0.257 & 0.554 & 0.435 & 0.887 \\
\hline & {$[0.11]$} & {$[0.10]$} & {$[0.60]$} & {$[1.02]$} & {$[0.79]$} & {$[1.46]$} \\
\hline \multirow[t]{2}{*}{$\%$ \%vote_others_defeatedcandidate 2008} & $-0.8 * * *$ & $-0.8 * * *$ & $-1.2 * * *$ & $-1.4 * * *$ & $-1.5 * * *$ & $-1.9 * * *$ \\
\hline & {$[-2.74]$} & {$[-2.61]$} & {$[-3.19]$} & {$[-2.71]$} & {$[-2.79]$} & {$[-3.12]$} \\
\hline \multirow[t]{2}{*}{ Monsoon rain } & -0.003 & -0.004 & -0.007 & -0.006 & -0.006 & -0.007 \\
\hline & {$[-0.35]$} & {$[-0.59]$} & {$[-0.86]$} & {$[-0.72]$} & {$[-0.70]$} & {$[-0.74]$} \\
\hline \multirow[t]{2}{*}{ Average $\mathrm{HH}$ size } & 0.010 & 0.003 & 0.001 & 0.000 & 0.002 & 0.010 \\
\hline & {$[0.84]$} & {$[0.24]$} & {$[0.10]$} & {$[0.00]$} & {$[0.14]$} & {$[0.70]$} \\
\hline \multirow[t]{2}{*}{ pct_BPLhh } & 0.033 & 0.032 & 0.040 & 0.033 & 0.017 & 0.043 \\
\hline & {$[0.55]$} & {$[0.51]$} & {$[0.57]$} & {$[0.46]$} & {$[0.22]$} & {$[0.58]$} \\
\hline \multirow[t]{2}{*}{ pct_Minority_hh } & -0.074 & -0.071 & -0.055 & -0.051 & -0.041 & -0.044 \\
\hline & {$[-0.81]$} & {$[-0.76]$} & {$[-0.56]$} & {$[-0.46]$} & {$[-0.37]$} & {$[-0.38]$} \\
\hline \multirow[t]{2}{*}{ Worker to Non-Worker Ratio } & $137.5 * * *$ & $133.8 * * *$ & $147.6 * * *$ & $154.7 * * *$ & $160.0 * * *$ & $175.1 * * *$ \\
\hline & [4.98] & {$[4.74]$} & {$[4.86]$} & {$[4.79]$} & {$[4.73]$} & {$[5.13]$} \\
\hline \multirow[t]{2}{*}{ sex_member_2008==Male } & -0.376 & 1.105 & 2.629 & 1.778 & 2.525 & -0.124 \\
\hline & {$[-0.11]$} & {$[0.31]$} & {$[0.68]$} & {$[0.45]$} & {$[0.62]$} & {$[-0.03]$} \\
\hline \multirow[t]{2}{*}{ caste_member_2008 $==\mathrm{SC}$} & $-9.1 * *$ & $-9.0 * *$ & $-7.6 *$ & $-7.7 *$ & $-8.4^{*}$ & $-7.7 *$ \\
\hline & {$[-2.16]$} & {$[-2.12]$} & {$[-1.73]$} & {$[-1.69]$} & {$[-1.84]$} & {$[-1.68]$} \\
\hline \multirow[t]{2}{*}{ caste_member_2008 $==\mathrm{ST}$} & -2.147 & -1.183 & 2.685 & 3.221 & 9.374 & 13.677 \\
\hline & {$[-0.34]$} & {$[-0.18]$} & {$[0.32]$} & {$[0.34]$} & {$[0.86]$} & {$[1.18]$} \\
\hline \multirow[t]{2}{*}{ caste_member_2008 $==\mathrm{OBC}$} & -7.745 & -8.167 & -6.837 & -3.047 & -2.471 & 0.663 \\
\hline & {$[-1.22]$} & {$[-1.25]$} & {$[-0.96]$} & {$[-0.42]$} & {$[-0.32]$} & {$[0.08]$} \\
\hline \multirow[t]{2}{*}{ caste_member_2008 $==$ Muslim } & $-17.4 * * *$ & $-17.5 * * *$ & $-21.0 * * *$ & $-20.6 * * *$ & $-19.6 * * *$ & $-22.0 * * *$ \\
\hline & {$[-3.09]$} & {$[-3.08]$} & {$[-3.77]$} & {$[-3.67]$} & {$[-3.38]$} & {$[-3.62]$} \\
\hline \multirow[t]{2}{*}{ year $==2011$} & $12.5^{* *}$ & $13.3 * * *$ & $13.1 * *$ & $13.5^{* *}$ & $14.1 * *$ & $14.3 * *$ \\
\hline & {$[2.57]$} & {$[2.64]$} & {$[2.48]$} & {$[2.46]$} & {$[2.49]$} & {$[2.47]$} \\
\hline \multirow[t]{2}{*}{ year $==2012$} & 4.670 & 6.044 & 5.422 & 5.846 & 7.199 & 7.045 \\
\hline & {$[1.16]$} & {$[1.50]$} & {$[1.31]$} & [1.39] & {$[1.62]$} & {$[1.54]$} \\
\hline \multirow[t]{2}{*}{ district $==$ Purulia } & 6.983 & 2.932 & -2.535 & -5.450 & -2.668 & -1.376 \\
\hline & {$[0.43]$} & {$[0.18]$} & {$[-0.14]$} & {$[-0.30]$} & {$[-0.14]$} & {$[-0.06]$} \\
\hline \multirow[t]{2}{*}{ district $==$ South 24 Parganas } & $39.9 * * *$ & $37.6 * * *$ & $34.7 * *$ & $38.1 * *$ & $42.7 * *$ & $51.2 * *$ \\
\hline & {$[2.91]$} & {$[2.65]$} & {$[2.25]$} & {$[2.31]$} & {$[2.32]$} & {$[2.53]$} \\
\hline Observations & 573 & 553 & 517 & 490 & 474 & 457 \\
\hline$R^{2}$ & 0.073 & 0.056 & 0.073 & 0.080 & 0.078 & 0.099 \\
\hline $\mathrm{F}$ & 3.167 & 3.036 & 3.230 & 3.047 & 3.019 & 3.015 \\
\hline
\end{tabular}

$t$ statistics in brackets; ${ }^{*} \mathrm{p}<0.10,{ }^{* *} \mathrm{p}<0.05, * * * \mathrm{p}<0.01$ 
Appendix 6

Table 6A: Comparison of village level vote share of TMC and CPIM in 2008 and 2009 Election: by GP level ruling party and by Treatment

Village

\begin{tabular}{|c|c|c|c|c|c|c|c|c|c|c|c|c|c|c|}
\hline & \multicolumn{4}{|c|}{ TMC GP } & \multicolumn{4}{|c|}{ CPIM GP } & \multicolumn{4}{|c|}{ Any GP } & \multicolumn{2}{|c|}{ Any GP } \\
\hline & \multicolumn{2}{|c|}{$\mathrm{T}=1$} & \multicolumn{2}{|c|}{$\mathrm{T}=0$} & \multicolumn{2}{|c|}{$\mathrm{T}=1$} & \multicolumn{2}{|c|}{$\mathrm{T}=0$} & \multicolumn{2}{|c|}{$\mathrm{T}=1$} & \multicolumn{2}{|c|}{$\mathrm{T}=0$} & \multicolumn{2}{|c|}{ Any $T$} \\
\hline $\begin{array}{l}\text { Ward level vote share } \\
\text { Election Year }\end{array}$ & TMC & CPIM & TMC & CPIM & TMC & CPIM & TMC & CPIM & TMC & CPIM & TMC & CPIM & TMC & CPIM \\
\hline 2008 & 55.01 & 35.05 & 31.01 & 43.72 & 12.46 & 61.82 & 39.92 & 36.88 & 22.59 & 49.2 & 23.23 & 38.2 & 22.79 & 45.81 \\
\hline 2013 & 62.98 & 29.15 & 33.18 & 34.18 & 34.04 & 34.90 & 41.54 & 32.97 & 39.80 & 29.9 & 37.95 & 29.8 & 39.22 & 29.89 \\
\hline t-test of mean difference & $(2.14)^{* *}$ & $(1.72)^{*}$ & $(0.77)$ & $(1.08)$ & $(3.82)^{* * *}$ & $(2.88)^{* * *}$ & (1.46) & $(0.79)$ & $(2.1)^{* *}$ & $(2.2)^{* *}$ & (1.49) & (1.1) & $(1.66)^{*}$ & $(1.72)^{*}$ \\
\hline $\mathrm{N}$ & 329 & 329 & 121 & 121 & 673 & 673 & 296 & 296 & 1174 & 1174 & 533 & 533 & 1707 & 1707 \\
\hline
\end{tabular}

Note: $\mathrm{T}=1$ implies the ward is a ruling party ward and $\mathrm{T}=0$ implies the ward is not a ruling party ward. 
Table 6B: Re-election Scenario by Treatment and by Party

\begin{tabular}{ccccc}
\hline & \multicolumn{2}{c}{ sample where T=1 i.e. only in treated village } & $\begin{array}{c}\text { Sample with any T i.e. any } \\
\text { village }\end{array}$ \\
\cline { 2 - 5 } & $\begin{array}{c}\text { TMC Village/ward in } \\
2008\end{array}$ & $\begin{array}{c}\text { CPIM Village/ward in } \\
2008\end{array}$ & $\begin{array}{c}\text { TMC } \\
\text { Village/ward } \\
\text { in 2008 }\end{array}$ & $\begin{array}{c}\text { CPIM } \\
\text { Village/ward } \\
\text { in 2008 }\end{array}$ \\
\hline $\begin{array}{c}\text { Share of constituencies where } \\
\text { party gets re-elected } \\
\text { in 2013 }\end{array}$ & 63.83 & 22.10 & 44.30 & 26.15 \\
\hline $\mathrm{N}$ & 329 & 673 & 474 & 826 \\
\hline
\end{tabular}

